\title{
Evaluation of the Prediction Capability of AHP and F_AHP Methods in Flood Susceptibility Mapping of Ernakulam District (India)
}

RESHMA VILASAN ( $\nabla$ reshmavilasan@gmail.com )

Visvesvaraya National Institute of Technology https://orcid.org/0000-0002-6401-1548

\section{Vijay S Kapse}

Visvesvaraya National Institute of Technology

\section{Research Article}

Keywords: Analytical hierarchy process, Flood susceptible zones, Fuzzy-AHP, GIS

Posted Date: June 29th, 2021

DOl: https://doi.org/10.21203/rs.3.rs-655658/v1

License: (c) (i) This work is licensed under a Creative Commons Attribution 4.0 International License.

Read Full License

Version of Record: A version of this preprint was published at Natural Hazards on March 9th, 2022. See the published version at https://doi.org/10.1007/s11069-022-05248-4. 


\title{
Evaluation of the prediction capability of AHP and F_AHP methods in flood susceptibility mapping of Ernakulam district (India)
}

\author{
Reshma T Vilasan ${ }^{1}$, Vijay S Kapse ${ }^{2}$ \\ ${ }^{1} \mathrm{Ph} . \mathrm{D}$. Scholar, Visvesvaraya National Institute of Technology, Nagpur, India \\ ${ }^{2}$ Head of Department, Visvesvaraya National Institute of Technology, Nagpur, India
}

\begin{abstract}
Floods are one of the frequent natural hazards occurring in Kerala because of the remarkably high annual rate of rainfall. The objective of this study is to prepare the flood susceptibility maps of the Ernakulam district by integrating remote sensing data, GIS, and analytical hierarchy process (AHP), and fuzzy-analytical hierarchy process methods. Factors such as slope angle, soil types (texture), land use/land cover, stream density, water ratio index, normalized difference built-up index, topographic wetness index, stream power index, aspect, sediment transport index have been selected. The area of the final maps is grouped into five flood susceptible zones, ranging from very low to very high. The major reasons for flood occurrence in Ernakulam district are the combined effect of multiple factors such as excess silting, reduction of stream width due to human intervention, and changes in land cover and land use pattern, lower slope, higher soil moisture content, lower stream capacity, and poor infiltration capacity of soils. The prepared map was validated using the receiver operating characteristic (ROC) curve method. The area under the ROC curve (AUC) values of 0.75 and 0.81 estimated by the ROC curve method for the AHP and F-AHP methods is considered acceptable and excellent, which confirms the prediction capability of the prepared maps. The very high susceptible zone constitutes around $19 \%$ of the district. This map is useful for land-use planners and policymakers to adopt strategies which will reduce the impact of flood hazard and damage in the future.
\end{abstract}

Keywords: Analytical hierarchy process, Flood susceptible zones, Fuzzy-AHP, GIS

\section{Introduction}

Flooding is one of the natural hazards that often cause significant damage to property and loss of life (Merkuryeva et al. 2015). This condition can arise from diverse hydrological processes, such as high tide levels, precipitation, high groundwater levels, and high river flows (Acreman and Holden 2013). Fluvial floods can be defined as the overflowing of streams or other water bodies of accumulated water over areas that are not normally inundated with water (Pratomo et al. 2016). The frequency of flooding is expected to increase due to unscientific modifications of drainage channels and unplanned development in the drainage basin because of urbanization, deforestation, and prolonged rainfall (Tehrany et al. 2015). Fluvial floods can occur due to the clogging of river channels because of sedimentation (Martín-Vide et al. 2014), snowmelt, or, in rare cases, dam collapse (Acreman and Holden 2013). Multiple factors, including heavy rainfall, poor infiltration capability of the soil, climate change, changes in land-use patterns, can lead to flooding (Ali et al. 2020). Floods can cause infrastructure losses (transportation networks, communication networks, etc.), residential losses, public facilities losses, and agricultural losses (damages to land, productivity, crop loss), and impact on water quality, accessibility, and availability (Petersen 2001; Smiley and Hambati 2019). Drowning, electrical injuries, and hypothermia are the direct health consequences, while indirect health effects include displacement of populations, intermittent disruption of public health services, lower income, and insufficient temporary living conditions (Allaire 2018). 
Flooding can cause mortality, injuries, mental disorder, and transmission of fecal-oral diseases (Cholera, Cryptosporidiosis, Diarrhea, Poliomyelitis, Rotavirus, Typhoid, Paratyphoid, etc.), rodent-borne diseases (Hantavirus pulmonary syndrome, Leptospirosis, etc.), vector-borne diseases (Malaria, Lymphatic filariasis, and Arbovirus disease) (Ahern et al. 2005).

Flooding is one of the frequently occurring natural hazards in India. India is one of the worst-affected countries in the world after Bangladesh (Panda and Sahoo 2015). About 40 million hectares (almost 12\% of the area) of India are susceptible to floods (Husain 2012). India receives $75 \%$ of the rain during the $\mathrm{S}-\mathrm{W}$ monsoon season (June-September) (Agnihotri and Mohapatra 2012). Most of the rivers overflow during this period, resulting in intense recurring floods. The devastating floods of 2018 and 2019 caused significant damage to infrastructure, property and resulted in hundreds of deaths in Kerala (Mishra and Shah 2018; Government of Kerala 2019; Hunt and Menon 2020). The flood-hit Kerala faced diseases such as Chikungunya, Dengue, Cholera, Typhoid, Hepatitis, and Leptospirosis (Jobin and Prakash 2020). Leptospirosis has long been a major threat to Kerala with more than 1000 cases reported annually (James et al. 2018). By providing the public with accurate information on flood risk through flood susceptibility maps, the damages and losses can be minimized.

Remote sensing (RS) and GIS have made significant contributions in disaster management studies such as those related to floods (Brivio et al. 2002; Dewan et al. 2006; Fernández and Lutz 2010; Paquette and Lowry 2012; Ajin et al. 2013; Tiryaki and Karaca 2018; Ajin et al. 2019; Ullah and Zhang 2020; Msabi and Makonyo 2021), droughts (Krishna et al. 2009; Muthumanickam et al. 2011; Belal et al. 2014; Legesse and Suryabhagavan 2014; Dutta et al. 2015; Orimoloye et al. 2019), forest fires (Adab et al. 2013; Ajin et al. 2018; Jaiswal et al. 2002; Abedi Gheshlaghi 2019; Bentekhici et al. 2020; Parajuli et al. 2020), landslides (Shahabi and Hashim 2015; Ajin et al. 2016; Anis et al. 2019; Berhane et al. 2020). The AHP method has been effectively used by many researchers (Rahman et al. 2019; Vojtek and Vojteková 2019; Das 2020; Domakinis et al. 2020; Souissi et al. 2020; Swain et al. 2020) to demarcate flood susceptible zones. While researchers like Bouamrane et al. (2020) and Kumi-Boateng et al. (2020) used both AHP and F-AHP methods to delineate flood susceptible zones. The objectives of this study are to delineate the flood susceptible zones in the Ernakulam district by integrating RS data and GIS, to compare the prediction capability of both AHP and F-AHP methods, to understand and analyze the recent induced reasons for the occurrence of floods. Ten causative factors, namely slope angle, soil types (texture), land use/land cover (LULC), stream density, water ratio index (WRI), normalized difference built-up index (NDBI), topographic wetness index (TWI), stream power index (SPI), slope aspect, and sediment transport index (STI) have been selected for the mapping process.

\section{Materials and methods}

\subsection{Study area}

The study area, Ernakulam district is situated almost in the middle of Kerala State and on the coast of the Arabian Sea. The district lies between the longitude of $76^{\circ} 16^{\prime} 48.00^{\prime \prime}$ and latitude of $9^{\circ} 58^{\prime} 48.00^{\prime \prime} \mathrm{N}$ and spans an area of about 3068 Sq.Km (Figure 1). The district is bounded on the North by Thrissur District, on the south by Kottayam and Alappuzha Districts, and on the east by Idukki district and the Arabian Sea lies all along the western boundary of the District. The climate in the area is tropical humid, with a long hot season and plenty of seasonal rainfall. A part of the Western Ghats forms the hilly tract along the eastern portion. Figure 1 shows the location of the study 
area. The district receives on an average $3450 \mathrm{~mm}$ of annual rainfall. South-west monsoon contributes about $67.4 \%$ to annual rainfall. About 30 percent of the area is urban where about 49 percent of the district's population live (Census, 2011).

\subsection{Data source}

The Ernakulam district is covered by topographic maps numbered $58 \mathrm{~B} / 4,58 \mathrm{~B} / 7,58 \mathrm{~B} / 8,58 \mathrm{~B} / 11,58 \mathrm{~B} / 12,58$ $\mathrm{B} / 15,58 \mathrm{~B} / 16,58 \mathrm{C} / 1,58 \mathrm{C} / 5,58 \mathrm{C} / 9,58 \mathrm{~F} / 3,58 \mathrm{~F} / 4$ at a scale of 1:50,000. The data used in this study include SoI topographic maps, Landsat 8 OLI (Operational land imager) satellite images of $30 \mathrm{~m}$ spatial resolution, SRTM (Shuttle radar topography mission) DEM (Digital elevation model) of $30 \mathrm{~m}$ spatial resolution, and soil data collected from the Kerala State Land Use Board (KSLUB) at 1:250,000 scale. After projecting the data to Universal Transverse Mercator (WGS 84; 43N), the thematic map layers of the factors such as slope, soil, land use/land cover, stream density, WRI, NDBI, TWI, SPI, aspect, and STI were generated using ESRI ArcGIS 10.8 and ERDAS Imagine 8.4 software tools. The map layers of factors such as slope, stream density, WRI, NDBI, TWI, SPI, aspect, and STI were classified using the natural breaks (Jenks) classification method (Mersha and Meten 2020; Ahmadlou et al. 2021). The thematic map layers were resampled to $30 \mathrm{~m} \times 30 \mathrm{~m}$ pixel size and the flood susceptibility maps were created using ArcGIS (Map algebra) tools after assigning the AHP and F-AHP weights. The AHP weights were computed using Microsoft Excel and the F-AHP weights were determined using FisPro 3.7. The flood susceptibility maps were validated using the flood inundation data of the years 2013, 2018 and 2019 collected from the records of the National Remote Sensing Centre (NRSC), Hyderabad, India. The ROC curves were plotted using the RStudio software to validate the prepared susceptibility maps.

\subsection{Causative factors}

\section{Slope angle}

The rate of infiltration and volume of water retention decreases with an increase in slope (Tehrany et al. 2017). The slope of the study area was derived from the SRTM DEM using ArcGIS spatial analyst tools. The slope angle of the Ernakulam district has been classified into five classes including, $0-5.00,5.00-11.88,11.88-21.26$, 21.26 - 33.46, and 33.46 - 79.75 (Figure 2). In this district, areas most seriously affected by floods have lower slope values $\left(0-5.00^{\circ}\right)$.

\section{Soil types}

Soil types are important as far as the vulnerability to flooding of an area is concerned. Soils with lower porosity have less pore spaces and hence a lower infiltration rate, and the decrease in infiltration leads to higher runoff and greater flooding potential (Gregory et al. 2016). The steady-state infiltration rate of sand, loam, and clay are $>0.8$ $\mathrm{in} / \mathrm{hr}, 0.2-0.4 \mathrm{in} / \mathrm{hr}$, and 0.04-0.2 in/hr respectively (Hillel 1982). The infiltration during rainfall events is controlled by hydraulic conductivity, and because of larger pores, sandy soil has higher hydraulic conductivity than finetextured soils (Prachansri 2017). As a result, areas with clayey soil are more prone to flooding. The soil layer was digitized from the soil map published by KSLUB in ESRI ArcGIS 10.6. In general, five different types of soil are observed (Figure 3) as clay, gravelly clay, loam, gravelly loam, and sand. 
116 The land cover of a region is usually classified based on the amount and type of vegetation, which reflects its use,

117 environment, cultivation, and seasonal phenology (El Morjani et al. 2017). The urban and industrial areas have

118 been subjected to topographic modification due to human intervention. These areas are mainly made of impervious

119 surfaces such as buildings and roads, which reduce the volume of water naturally available for infiltration and

120 hence increase the volume of overland flow causing floods (Gigović et al. 2017). Built-up areas obstruct natural

121 drainage, leading to flooding. The land use and land cover types were derived from the Landsat 8 OLI satellite

122 image acquired in the year 2020 using ERDAS Imagine software. The maximum likelihood classifier (Ayele et

123 al. 2018; Alam et al. 2020) was used to classify the different land use/land cover types of the district. The land

124 use/land cover types of the district are deciduous forest, evergreen forest, scrubland, barren land, built-up area,

125 agricultural land, wetland, mixed vegetation, and water body (Figure 4). In the present study, the flood-affected

126 areas are intensely cultivated terrains, especially the paddy fields, and hence, the loss of agricultural land and

127 related economic losses will be remarkably high.

\section{Stream density}

129 Stream densities are closely linked to various hydrological processes such as infiltration, saturation of the soil, 130 sheet erosion, overland flows, and the interactions between them to regulate sediment and runoff (Moglen et al. 131 1998). However, higher stream density need not imply a higher rate of runoff. This is because the stream capacity 132 depends on the width, depth, and length of drainage channels. In the study area, the distributaries of the 133 mainstream are narrow, tortuous, and shallow. Therefore, water retention leads to flooding. In addition to this, the 134 existing narrow stream channels in the lower parts of the study area are partially blocked due to heavy silting. 135 This explains the frequent flooding of the lower stretches of the Ernakulam district. The stream networks were 136 digitized from the SoI topographic maps and the stream density layer was prepared using ArcGIS spatial analyst 137 tools. The stream density of the study area is grouped into five classes (Figure 5). They are $0-1.47 \mathrm{~km} / \mathrm{km}^{2}, 1.47-$ $138 \quad 3.17 \mathrm{~km} / \mathrm{km}^{2}, 3.17-6.02 \mathrm{~km} / \mathrm{km}^{2}, 6.02-12.78 \mathrm{~km} / \mathrm{km}^{2}$, and $12.78-26.94 \mathrm{~km} / \mathrm{km}^{2}$.

\section{WRI}

140 WRI of the Ernakulam district was derived from the Landsat 8 OLI images using Equation 1 (Shen and Li 2010) and ArcGIS tools.

$$
\mathrm{WRI}=\frac{(\text { Green+Red })}{(\mathrm{NIR}+\mathrm{SWIR})}
$$

143 The WRI value above 1 represents water (Shen and Li 2010). The WRI of the study area ranges between 0.26 and 1441.42 (Figure 6) and is categorized into five classes (0.26-0.46, 0.46-0.56, 0.56-0.70, 0.70-0.98, and 0.98-1.42). 145 The chance of flooding is high in areas with higher WRI.

\section{NDBI}

147 NDBI is a satellite-derived index that represents urban built-up areas (Bhatti and Tripathi 2014). The NDBI value 148 close to 0 represents woodland, the NDBI value less than 0 represents a body of water, and the NDBI value greater 149 than 0 represents built-up areas (Zha et al. 2003). NDBI was extracted using Equation 2 (Shahfahad et al. 2020) and ArcGIS spatial analyst tools. 
$151 \quad \mathrm{NDBI}=\frac{\text { SWIR-NIR }}{\text { SWIR+NIR }}$

152 NDBI of Ernakulam district is grouped into five classes: $-0.43--0.21,-0.21--0.14,-0.14--0.07,-0.07-0.00$, 153 and $0.00-0.43$ (Figure 7). The chance of flooding is high in areas with higher NDBI.

\section{TWI}

155 TWI represents the soil moisture content and surface saturation (Yong et al. 2012). Higher soil moisture content 156 and soil saturation favour flooding (Ho-Hagemann et al. 2015). When the saturation level increases, the local 157 groundwater table rises. Eventually, the zone of aeration becomes fully saturated, setting the condition for 158 flooding. Therefore, the areas with higher TWI are more prone to flooding. The TWI of the study area was derived 159 from the SRTM DEM. TWI was computed using Equation 3 (Beven and Kirkby 1979) and spatial analyst tools 160 with ArcGIS software.

$161 \quad$ TWI $=\ln (\alpha / \tan \beta)$

162 Where $\alpha$ is the specific catchment area $(\mathrm{A}=A / L$, catchment area $(A)$ divided by contour length $(L)]$ and $\beta$ is the 163 local slope

164 The present study has classified the district into 5 classes $(0.61-6.82,6.82-19.38,19.38-41.61,41.61-80.26$, and $16580.26-246.45$ ) based on TWI as shown in Figure 8. This study confirms the fact that the areas affected by frequent 166 floods in the study area are characterized by the highest TWI (80.26-246.45).

\section{SPI}

168 SPI is the water flow power in terms of erosion (Altin and Gökkaya 2015). It determines the capacity of a river to 169 carry sediment (Bizzi and Lerner 2015). In the upstream segment, because of higher stream power, the streams 170 can erode and transport a significant volume of debris. The channels become shallow and meandering when the 171 stream power is declined, resulting in overbank deposition of sediment (Graf 1983). This is a major reason for 172 flooding on the lower plains. The SPI was derived from the SRTM-DEM. SPI was calculated using Equation 4 173 (Moore et al. 1991).

$174 \quad \mathrm{SPI}=\alpha \tan \beta$

175 Where $\alpha$ is the specific catchment area $(\mathrm{A}=A / L$, catchment area $(A)$ divided by contour length $(L)]$ and $\beta$ is the 176 local slope.

177 The present study has classified the Ernakulam district into 5 classes $(-38.15--5.19,-5.19--2.08,-2.08--0.65$, $178-0.65-0.29$, and $0.29-22.75$ ) based on the stream power index as shown in the map (Figure 9). It was found that 179 most of the flood-affected areas have the lowest SPI (-38.15 - -5.19).

\section{Slope aspect}

181 The slope aspect (Figure 10) of the study area was prepared from the SRTM DEM using ArcGIS spatial analyst 182 tools and has been grouped into nine classes (Flat, North, Northeast, East, Southeast, South, Southwest, West, and 183 Northwest). Because of the rapid accumulation of water, flooding is more likely in areas with flat aspects. The 
southern and western aspects will be drier and less prone to flooding, as there are greater solar and wind influences in the southern aspects and a higher heating intensity in the western aspects (Setiawan et al. 2004).

STI refers to sediment movement caused by water flow (Tehrany et al. 2019). STI characterizes erosion and deposition processes (Kalantari et al. 2014; Kumar and Gupta 2016). The high STI reflects the erosion process, whereas the low STI reflects the deposition process. STI was derived from the SRTM DEM using Eq. 5 (Moore et al. 1993) and ArcGIS spatial analyst tools.

191

$\mathrm{STI}=\left(\frac{\alpha}{22.13}\right)^{0.6}\left(\frac{\sin \beta}{0.0896}\right)^{1.3}$

Where $\alpha$ is the area of the catchment $\left(\mathrm{m}^{2}\right)$ and $\beta$ (radians) is the slope gradient.

The STI of the study area ranges from 0 to 247.77 and is grouped into 5 classes (Figure 11). The chance of flooding will be high in areas with low SPI values, as these as depositional zones. The carrying capacity of stream channels in these zones will be much reduced due to the deposition of sediments.

\subsection{The AHP modelling}

AHP is the most used decision-making method developed by Saaty (1980) to solve complex decision problems. By reducing complicated decisions to a number of pairwise comparisons, AHP helps to make the right decision and calculates the results (Dekrita et al. 2019). For constructing judgement matrices, a 1-9 scale is used. The important steps involved in AHP are the development of a pairwise comparison matrix, calculation of Eigen value, Eigen vector and weighting coefficient (Table 1), and finally, calculation of consistency ratio to check the consistency (Table 2).

\section{INSERT TABLE 1 HERE}

Where Slp. $=$ Slope angle; $\mathrm{SD}=$ Stream density, Asp. $=$ Slope aspect

The eigen vector $(\mathrm{Vp})$, and weighting coefficient $(\mathrm{Cp})$ were computed using Equations 6 and 7 (Danumah et al.

Where $k=$ number of factors and $W=$ ratings of the factors

$\mathrm{Cp}=\frac{V p}{V p 1+\ldots \ldots . V p k}$

\section{INSERT TABLE 2 HERE}

211 The eigen value ( $\lambda$ max), consistency index (CI), and consistency ratio (CR) were computed using Equations 8,

2129 , and 10 (Danumah et al. 2016) 
$215 \quad \mathrm{CR}=\frac{C I}{R I}$

Where RI is the random index

Table 3 Random index (Saaty 1980)

\begin{tabular}{|c|c|c|c|c|c|c|c|c|c|c|}
\hline Number of criteria & 2 & 3 & 4 & 5 & 6 & 7 & 8 & 9 & 10 & 11 \\
\hline RI & 0.00 & 0.58 & 0.90 & 1.12 & 1.24 & 1.32 & 1.41 & 1.45 & 1.49 & 1.51 \\
\hline
\end{tabular}

218

220

221

$237 \quad \tilde{A}^{k}=\left[\begin{array}{cccc}\tilde{d}_{11}^{k} & \tilde{d}_{12}^{k} & \ldots & \tilde{d}_{1 n}^{k} \\ \tilde{d}_{21}^{k} & \ldots & \ldots & \tilde{d}_{2 n}^{k} \\ \ldots & \ldots & \ldots & \ldots \\ \tilde{d}_{n 1}^{k} & \tilde{d}_{n 2}^{k} & \ldots & \tilde{d}_{m n}^{k}\end{array}\right]$ are acceptable.

\subsection{The Fuzzy-AHP modelling}

$$
\tilde{A}^{k}=\left[\begin{array}{cccc}
\tilde{d}_{11}^{k} & \tilde{d}_{12}^{k} & \ldots & \tilde{d}_{1 n}^{k} \\
\tilde{d}_{21}^{k} & \ldots & \ldots & \tilde{d}_{2 n}^{k} \\
\ldots & \ldots & \ldots & \ldots \\
\tilde{d}_{n 1}^{k} & \tilde{d}_{n 2}^{k} & \ldots & \tilde{d}_{m n}^{k}
\end{array}\right]
$$

The CR should be less than 0.1 (i.e., 10\%) (Saaty 1980), otherwise, the judgements are untrustworthy and need to revise the subjective judgements. In this study, the CR is 0.041 (which is less than 0.1 ), hence the judgements

The final weights obtained through the AHP model are shown in Equation 11.

$$
\begin{aligned}
& \mathrm{FSZ}=(0.291 \times \text { Slp. })+(0.216 \times \text { Soil })+(0.155 \times \text { LULC })+(0.110 \times \mathrm{SD})+(0.077 \times \text { WRI })+(0.054 \times \\
& \mathrm{NDBI})+(0.038 \times \mathrm{TWI})+(0.027 \times \mathrm{SPI})+(0.019 \times \text { Asp. })+(0.014 \times \mathrm{STI})
\end{aligned}
$$

F-AHP is an AHP approach developed utilizing the theory of fuzzy logic (Putra et al. 2018). The fuzzy approach that represents uncertainty in human judgements together with the AHP method can be used to provide more precise, specific, and realistic outcomes (Kaya et al. 2020; Lin 2020). In this study, the Buckley (1985) technique was followed by comparing the fuzzy ratios described as triangular membership functions. The major processes involved are the construction of pair-wise comparison of factors (Table 4), calculation of the geometric means of fuzzy comparison values (Table 5), relative fuzzy weights of each factor (Table 6), and averaged and normalized relative weights of factor (Table 7). The various steps involved with the F-AHP modelling are as follows:

Step 1: Comparison of the factors or alternatives by decision-makers

For example: if the decision-maker states that factor 1 (P1) is weakly significant than factor 2 (P2), then the fuzzy triangular scale will be $(2,3,4)$. In the pair-wise contribution matrix of the factor for comparison of P2 to P1, the fuzzy triangular scale will be $(1 / 4,1 / 3,1 / 2)$ (Ayhan 2013).

The pair-wise contribution matrix is depicted in Eq. 12.

Where $d_{i j}^{b}$ indicates the $\mathrm{k}^{\text {th }}$ decision maker's preference of $\mathrm{i}^{\text {th }}$ factor over $\mathrm{j}^{\text {th }}$ factor (Ayhan 2013). 
239 Step 2: When there is more than one decision-maker, the preferences $\left(g_{i j}^{6}\right)$ are averaged, and $\left(\tilde{d}_{i j}\right)$ is determined 240 using Eq. 13.

$241 \quad \tilde{d}_{i j}=\frac{\sum_{k=1}^{K} \tilde{d}_{i j}^{k}}{K}$

242 Step 3: The pair-wise comparison matrix is modified based on the averaged preferences using Eq. 14.

$243 \quad \tilde{A}=\left[\begin{array}{ccc}\tilde{d}_{11} & \cdots & \tilde{d}_{1 n} \\ \vdots & \ddots & \vdots \\ \tilde{d}_{n 1} & \cdots & \tilde{d}_{n n}\end{array}\right]$

Step 4: The geometric average of fuzzy comparative values for each factor was determined using Eq. 15 (Buckley 1985).

$247 \quad f / O=\left(\prod_{j=1}^{n} d_{i j}\right)^{1 / n}, i=1,2, \ldots ., n$

Where ${ }_{i}^{F / 4}$ still depicts the triangular values.

249

Step 5: From the next 3 sub-steps, the fuzzy weight of each factor was computed.

250

Step 5a: The vector summation of each ${ }_{i}^{F /}$ was determined.

251

Step 5b: The (-1) power of the summation vector was computed, and the fuzzy triangular number was replaced,

252 to convert it into increasing order.

Step 5c: To compute the fuzzy weight of factors $i\left(W_{l}\right)_{i}$, each ${ }_{i}^{F /}$ was multiplied with the reverse vector as in Eq. 16.

$$
\begin{aligned}
W_{l} & =f_{i} \otimes\left(f / \oplus f_{2} \oplus \ldots \oplus f_{n}\right)^{-1} \\
& =\left(l w_{i}, m w_{i}, u w_{i}\right)
\end{aligned}
$$

Step 6: The fuzzy weights were de-fuzzified using Eq. 17 (Chou and Chang 2008).

259

$M_{i}=\frac{l w_{i}, m w_{i}, u w_{i}}{3}$

Step 7: The Mi was standardized using Eq. 18. 
The final weights obtained from the F-AHP modelling are shown in Equation 19.

FSZ $=(0.282 \times$ Slp. $)+(0.215 \times$ Soil $)+(0.158 \times$ LULC $)+(0.112 \times$ SD $)+(0.078 \times$ WRI $)+(0.055 \times$

$\mathrm{NDBI})+(0.038 \times \mathrm{TWI})+(0.027 \times \mathrm{SPI})+(0.019 \times$ Asp. $)+(0.014 \times \mathrm{STI})$

\subsection{Validation of the flood susceptibility maps}

267

268

269

270

271

272

Finally, the flood susceptible zone map was validated using the flood inundation data provided by NRSC for the years 2013, 2018, and 2019. For the validation of the result, 570 locations within the flood inundated area were randomly selected (Figure 12). The receiver operating characteristic (ROC) curve analysis was performed using RStudio software to assess the prediction accuracy of the susceptibility map. When the area under ROC (AUC) equals 0.5, it indicates random chance and indicates perfect accuracy when AUC equals 1.0 (Zou et al. 2007). According to Hosmer and Lemeshow (2000), the AUC values are considered outstanding, excellent, and acceptable for values between 0.9-1.0, 0.8-0.9, and 0.7-0.8.

\section{Results and discussion}

The map layers of slope angle, soil, LULC, stream density, WRI, NDBI, TWI, SPI, aspect, and STI were combined using ArcGIS tools to prepare the flood susceptibility maps of the study area. The flood susceptibility maps were prepared using the weights derived by the AHP and F-AHP methods. The area of the flood susceptibility maps has been grouped into five classes, namely very low, low, moderate, high, and very high (Figure 13 and 14). The high and very high susceptible zones are located in the western parts of the study area. This area has a low slope, poor or very poorly drained soil, higher built-up developments, lower stream density, and high soil moisture content (WRI and TWI). The studies by Sarkar and Mondal (2020), Ullah and Zhang (2020) also found that high flood-prone areas are situated in areas with lower slopes and higher TWI. Like the findings of this study, Samanta et al. (2018) also found that the high and very flood susceptible zones are characterized by soils with poor to very poor drainage capacity. Ghosh and Mistri (2015) found that the reduced carrying capacity of stream channels due to excess siltation and drainage congestion is the major reason for flooding in the Damodar river basin. In their study, Erena and Worku (2018) also found that changes in the land use/land cover and encroachments of settlements (development activities) on the riverbank are the major reasons for flood risk. Bohorquez and del Moral-Erencia (2017) found vegetation encroachment as one of the major reasons for reduced stream channel capacity. The present study confirms that the flood occurring in this basin is due to the combined effect of natural factors, human intervention, and negligence in taking preventive measures. The area and percentage of each flood susceptible zone are shown in Table 8. The AUC values of 0.75 and 0.81 estimated by the ROC curve method confirm that the result is acceptable and excellent for the AHP and F-AHP modelling, respectively (Figure 15). This finding confirms that the F-AHP method is more effective in predicting flood-prone zones and was thus chosen as the best model. According to the F-AHP model, the very high susceptible zone covers $19.37 \%$ of the study area. 
Table 8 Area and percentage of flood susceptible zones

\begin{tabular}{|c|c|c|c|c|}
\hline \multirow{2}{*}{$\begin{array}{c}\text { Susceptible } \\
\text { Zones }\end{array}$} & $\begin{array}{c}\text { Area of } \\
\text { susceptible } \\
\text { zones } \\
\text { (Sq. km) }\end{array}$ & $\begin{array}{c}\text { Percentage of } \\
\text { the area of the } \\
\text { flood } \\
\text { susceptible } \\
\text { zones }\end{array}$ & $\begin{array}{c}\text { Area of } \\
\text { susceptible } \\
\text { zones } \\
\text { (Sq. km) }\end{array}$ & $\begin{array}{c}\text { Percentage } \\
\text { of the area } \\
\text { of the } \\
\text { flood } \\
\text { susceptible } \\
\text { zones }\end{array}$ \\
\hline Very low & 267.18 & 11.10 & 267.66 & 11.12 \\
\hline Low & 395.23 & 16.42 & 401.25 & 16.67 \\
\hline Moderate & 643.87 & 26.75 & 662.16 & 27.51 \\
\hline High & 623.41 & 25.90 & 609.69 & 25.33 \\
\hline Very high & 477.31 & 19.83 & 466.24 & 19.37 \\
\hline Total & $\mathbf{2 4 0 7}$ & $\mathbf{1 0 0}$ & $\mathbf{2 4 0 7}$ & $\mathbf{1 0 0}$ \\
\hline
\end{tabular}

297

298

299

300

301

302

303

304

305

306

307

308

309

310

311

312

313

314

315

316

317

318

319

320

\section{Conclusions}

Floods are one of the most common natural hazards occurring in the Ernakulam district and result in serious damage to agriculture, infrastructure, and human and animal habitats. This study applied GIS techniques, and AHP and F-AHP methods to prepare the flood susceptibility maps of the Ernakulam district. Floods occurring in this district are the result of natural factors such as low slope gradient, lower capacity of stream channels, higher soil moisture content, and poor infiltration capacity of soils, together with anthropogenic activities like blocking the natural stream channels for construction purposes. An excellent AUC value of 0.81 obtained by the ROC curve analysis for F-AHP proves the efficiency of the F-AHP method over the AHP method. The study confirms that around $19.37 \%$ of the basin falls under a very high susceptible zone. The present study demonstrated an effective model that can be used to delineate the flood susceptible zones, and this will help the land-use planners and policymakers to implement policies that can help mitigate flood risk and damage in the future.

\section{Ethics declarations}

Ethics Approval and Consent to Participate - This article does not contain any studies with human participants or animals performed by any of the authors. Informed consent is not applicable.

Conflict of Interest / Competing interests - The authors declare that they have no known competing financial interests or personal relationships that could have appeared to influence the work reported in this paper.

Availability of data and materials - Not applicable.

Financial interests - All authors certify that they have no affiliations with or involvement in any organization or entity with any financial interest or non-financial interest in the subject matter or materials discussed in this manuscript.

Author contributions - All the authors made significant contributions to the manuscript. All authors read and approved the final manuscript. 
323 Abedi Gheshlaghi H (2019) Using GIS to develop a model for forest fire risk mapping. Journal of the Indian

324 Society of Remote Sensing 47: 1173-1185. https://doi.org/10.1007/s12524-019-00981-z

Acreman M, Holden J (2013) How wetlands affect floods. Wetlands 33: 773-786. https://doi.org/10.1007/s13157013-0473-2

Adab H, Kanniah KD, Solaimani K (2013) Modeling forest fire risk in the northeast of Iran using remote sensing and GIS techniques. Natural Hazards 65: 1723-1743. https://doi.org/10.1007/s11069-012-0450-8 Agnihotri G, Mohapatra M (2012) Prediction of occurrence of daily summer monsoon precipitation over Karnataka. Meteorological Applications 19(2): 130-139. https://doi.org/10.1002/met.246

Ahern M, Kovats RS, Wilkinson P, Few R, Matthies F (2005) Global health impacts of floods: Epidemiologic evidence. Epidemiologic Reviews 27(1): 36-46. https://doi.org/10.1093/epirev/mxi004 Ahmadlou M, Al-Fugara A, Al-Shabeeb AR, Arora A, Al-Adamat R, Pham QB, Al-Ansari N, Linh NTT, Sajedi H (2021) Flood susceptibility mapping and assessment using a novel deep learning model combining multilayer perceptron and autoencoder neural networks. Journal of Flood Risk Management 14(1). https://doi.org/10.1111/jfr3.12683

Ajin RS, Krishnamurthy RR, Jayaprakash M, Vinod PG (2013) Flood hazard assessment of Vamanapuram river basin, Kerala, India: An approach using remote sensing and GIS techniques. Advances in Applied Science Research 4: 263-274.

Ajin RS, Loghin AM, Vinod PG, Jacob MK (2019) Flood hazard zone mapping in the tropical Achankovil river basin in Kerala: a study using remote sensing data and geographic information system. Journal of Wetlands Biodiversity 9: 45-58.

Ajin RS, Loghin AM, Vinod PG, Jacob MK, Krishnamurthy RR (2016) Landslide susceptible zone mapping using ARS and GIS techniques in selected taluks of Kottayam district, Kerala, India. International Journal of Applied Remote Sensing and GIS 3(1): 16-25.

Ajin RS, Loghin AM, Vinod PG, Menon ARR, Jacob MK (2018) Forest fire risk assessment using geospatial techniques: A study in Mannarkkad forest division of Palakkad district, Kerala, India. ECOTERRA - Journal of Environmental Research and Protection 15(1): 1-9.

Alam A, Bhat MS, Maheen M (2020) Using Landsat satellite data for assessing the land use and land cover change in Kashmir valley. GeoJournal 85: 1529-1543. https://doi.org/10.1007/s10708-019-10037-x Ali SA, Parvin F, Pham QB, Vojtek M, Vojteková J, Costache R, Linh NTT, Nguyen HQ, Ahmad A, Ghorbani MA (2020) GIS-based comparative assessment of flood susceptibility mapping using hybrid multi-criteria decision-making approach, naïve Bayes tree, bivariate statistics and logistic regression: A case of Topla basin, Slovakia. Ecological Indicators 117. https://doi.org/10.1016/j.ecolind.2020.106620 Allaire M (2018) Socio-economic impacts of flooding: A review of the empirical literature. Water Security 3: 1826. https://doi.org/10.1016/j.wasec.2018.09.002 Altin TB, Gökkaya E (2015) Landslide-triggering factors in Korucak sub basin, North Anatolian, Turkey. Procedia Earth and Planetary Science 15: 566-572. https://doi.org/10.1016/j.proeps.2015.08.104 using bivariate statistical methods in North-western Tunisia. Open Geosciences 11(1): 708-726. 
363 Time series land cover mapping and change detection analysis using geographic information system and remote sensing, Northern Ethiopia. Air, Soil and Water Research. https://doi.org/10.1177/1178622117751603 Ayhan MB (2013) A fuzzy AHP approach for supplier selection problem: A case study in a gear motor company. International Journal of Managing Value and Supply Chains 4(3): 11-23. https://doi.org/10.5121/ijmvsc.2013.4302 Belal AA, El-Ramady HR, Mohamed ES, Saleh AM (2014) Drought risk assessment using remote sensing and GIS techniques. Arabian Journal of Geosciences 7: 35-53. https://doi.org/10.1007/s12517-012-0707-2 Bentekhici N, Bellal SA, Zegrar A (2020) Contribution of remote sensing and GIS to mapping the fire risk of Mediterranean forest case of the forest massif of Tlemcen (North-West Algeria). Natural Hazards 104: 811-831. https://doi.org/10.1007/s11069-020-04191-6

373 Berhane G, Kebede M, Alfarah N, Hagos E, Grum B, Giday A, Abera T (2020) Landslide susceptibility zonation mapping using GIS-based frequency ratio model with multi-class spatial data-sets in the Adwa-Adigrat mountain chains, northern Ethiopia. Journal of African Earth Sciences 164. https://doi.org/10.1016/j.jafrearsci.2020.103795 Beven KJ, Kirkby MJ (1979) A physically based, variable contributing area model of basin hydrology. Hydrological Sciences Journal 24(1): 43-69. https://doi.org/10.1080/02626667909491834 Bizzi S, Lerner DN (2015) The use of stream power as an indicator of channel sensitivity to erosion and deposition processes. River Research and Applications 31(1): 16-27. https://doi.org/10.1002/rra.2717 Bohorquez P, del Moral-Erencia JD (2017) 100 years of competition between reduction in channel capacity and streamflow during floods in the Guadalquivir river (Southern Spain). Remote Sensing 9(7). https://doi.org/10.3390/rs9070727

383 Bouamrane A, Derdous O, Dahri N, Tachi SE, Boutebba K, Bouziane MT (2020) A comparison of the analytical hierarchy process and the fuzzy logic approach for flood susceptibility mapping in a semi-arid ungauged basin (Biskra basin: Algeria). International Journal of River Basin Management. https://doi.org/10.1080/15715124.2020.1830786

Brivio PA, Colombo R, Maggi M, Tomasoni R (2002) Integration of remote sensing data and GIS for accurate mapping of flooded areas. International Journal of Remote Sensing 23(3): 429-441. https://doi.org/10.1080/01431160010014729 Buckley JJ (1985) Fuzzy hierarchical analysis. Fuzzy Sets Systems 17(1): 233-247. Chou SW, Chang, YC (2008) The implementation factors that influence the ERP (Enterprise Resource Planning) benefits. Decision Support Systems 46(1): 149-157. Danumah JH, Odai SN, Saley BM, Szarzynski J, Thiel M, Kwaku A, Kouame FK, Akpa LY (2016) Flood risk assessment and mapping in Abidjan district using multi-criteria analysis (AHP) model and geoinformation techniques, (cote d'ivoire). Geoenvironmental Disasters 3. https://doi.org/10.1186/s40677-016-0044-y Das S (2020) Flood susceptibility mapping of the Western Ghat coastal belt using multi-source geospatial data and analytical hierarchy process (AHP). Remote Sensing Applications: Society and Environment 20. https://doi.org/10.1016/j.rsase.2020.100379

399 Dekrita YA, Yunus R, Citta AB, Yamin M (2019) Integration of balanced scorecard and analytical hierarchy process as a tool for determining the priority of the program strategy: Case study in Dr. Tc. Hillers Maumere hospital. 3rd International Conference on Accounting, Management and Economics 2018 (ICAME 2018), 
Dewan AM, Kumamoto T, Nishigaki M (2006) Flood hazard delineation in Greater Dhaka, Bangladesh using an integrated GIS and remote sensing approach. Geocarto International 21(2): 33-38. https://doi.org/10.1080/10106040608542381 Domakinis C, Mouratidis A, Voudouris K, Astaras T, Karypidou MC (2020) Flood susceptibility mapping in Erythropotamos river basin with the aid of Remote Sensing and GIS. AUC Geographica 55(2): 149-164. https://doi.org/10.14712/23361980.2020.11

410 Dutta D, Kundu A, Patel NR, Saha SK, Siddiqui AR (2015) Assessment of agricultural drought in Rajasthan

411 (India) using remote sensing derived vegetation condition index (VCI) and standardized precipitation index (SPI).

412 The Egyptian Journal of Remote Sensing and Space Science 18(1): 53-63.

413 https://doi.org/10.1016/j.ejrs.2015.03.006

414 El Morjani ZE, Seif Ennasr M, Elmouden A, Idbraim S, Bouaakaz B, Saad A (2017) Flood hazard mapping and 415 modeling using GIS applied to the Souss river watershed. In: Choukr-Allah R, Ragab R, Bouchaou L, Barceló D 416 (eds) The Souss-Massa river basin, Morocco (The handbook of environmental chemistry 53). Springer, 417 Switzerland, pp 57-93. https://doi.org/10.1007/698_2016_69

418 Erena SH, Worku H (2018) Flood risk analysis: causes and landscape based mitigation strategies in Dire Dawa 419 city, Ethiopia. Geoenvironmental Disasters 5. https://doi.org/10.1186/s40677-018-0110-8

420 Fernández DS, Lutz MA (2010) Urban flood hazard zoning in Tucumán Province, Argentina, using GIS and 421 multicriteria decision analysis. Engineering Geology 111(1-4): 90-98. 422 https://doi.org/10.1016/j.enggeo.2009.12.006

423 Ghosh S, Mistri B (2015) Geographic concerns on flood climate and flood hydrology in monsoon-dominated

424 Damodar river basin, Eastern India. Geography Journal. https://doi.org/10.1155/2015/486740

425 Gigović L, Pamučar D, Bajić Z, Drobnjak S (2017) Application of GIS-interval rough AHP methodology for 426 flood hazard mapping in urban areas. Water 9(6). https://doi.org/10.3390/w9060360

427 Government of Kerala (2019) Memorandum: Floods and landslides 2019, Department of Disaster Management,

428 Govt. of Kerala, pp 1-88. Available at https://sdma.kerala.gov.in/disaster-memoranda/

429 Graf W (1983) Downstream changes in stream power in the Henry Mountains, Utah. Annals of the Association 430 of American Geographers 73(3): 373-387.

431 Gregory JH, Dukes MD, Jones PH, Miller GL (2006) Effect of urban soil compaction on infiltration rate. Journal 432 of Soil and Water Conservation 61(3): 117-124.

433 Hillel D (1982) Introduction to Soil Physics. Academic Press, Massachusetts, United States of America.

434 Ho-Hagemann HTM, Hagemann S, Rockel B (2015) On the role of soil moisture in the generation of heavy 435 rainfall during the Oder flood event in July 1997. Tellus A: Dynamic Meteorology and Oceanography 67(1). 436 https://doi.org/10.3402/tellusa.v67.28661

437 Hosmer DW, Lemeshow S (2000) Applied logistic regression, Second edition. John Wiley \& Sons, Inc., United 438 States of America.

439 Hunt KMR, Menon A (2020) The 2018 Kerala floods: a climate change perspective. Climate Dynamics 54: 2433440 2446. https://doi.org/10.1007/s00382-020-05123-7 

India.

443 Jaiswal RK, Mukherjee S, Raju KD, Saxena R (2002) Forest fire risk zone mapping from satellite imagery and

444 GIS. International Journal of Applied Earth Observation and Geoinformation 4(1): 1-10. https://doi.org/10.1016/S0303-2434(02)00006-5

446 James S, Sathian B, van Teijlingen E, Asim M (2018) Outbreak of Leptospirosis in Kerala. Nepal Journal of 447 Epidemiology 8(4): 745-747. https://doi.org/10.3126/nje.v8i4.23876

448 Jobin SR, Prakash JW (2020) Outbreak of Leptospirosis in Kerala, India after floods: A survey. Plant Archives 449 20(1): 2560-2562.

450 Kalantari Z, Nickman A, Lyon SW, Olofsson B, Folkeson L (2014) A method for mapping flood hazard along 451 roads. Journal of Environmental Management 133: 69-77. https://doi.org/10.1016/j.jenvman.2013.11.032

452 Kaya I, Çolak M, Terzi F (2019) A comprehensive review of fuzzy multi criteria decision making methodologies 453 for energy policy making. Energy Strategy Reviews 24: 207-228. https://doi.org/10.1016/j.esr.2019.03.003

454 Krishna TM, Ravikumar G, Krishnaveni M (2009) Remote sensing based agricultural drought assessment in Palar 455 basin of Tamil Nadu state, India. Journal of the Indian Society of Remote Sensing 37: 9-20. 456 https://doi.org/10.1007/s12524-009-0008-8

457 Kumar S, Gupta S (2016) Geospatial approach in mapping soil erodibility using CartoDEM - A case study in 458 hilly watershed of Lower Himalayan range. Journal of Earth System Science 125(7): 1463-1472. 459 https://doi.org/10.1007/s12040-016-0738-2

460 Kumi-Boateng B, Peprah MS, Larbi EK (2020) The integration of analytical hierarchy process (AHP), fuzzy 461 analytical hierarchy process (FAHP), and Bayesian belief network (BBN) for flood-prone areas identification 462 A case study of the Greater Accra region, Ghana. Journal of Geomatics 14(2): 100-122.

463 Legesse G, Suryabhagavan KV (2014) Remote sensing and GIS based agricultural drought assessment in East Shewa Zone, Ethiopia. Tropical Ecology 55: 349-363.

465 Lin CN (2020) A fuzzy analytic hierarchy process-based analysis of the dynamic sustainable management index in leisure agriculture. Sustainability 12(13). https://doi.org/10.3390/su12135395

467 Martín-Vide JP, Amarilla M, Zárate FJ (2014) Collapse of the Pilcomayo river. Geomorphology 205: 155-163. 468 https://doi.org/10.1016/j.geomorph.2012.12.007

469 Merkuryeva G, Merkuryev Y, Sokolov BV, Potryasaev S, Zelentsov VA, Lektauers A (2015) Advanced river 470 flood monitoring, modelling and forecasting. Journal of Computational Science 10: 77-85. 471 https://doi.org/10.1016/j.jocs.2014.10.004

472 Mersha T, Meten M (2020) GIS-based landslide susceptibility mapping and assessment using bivariate statistical 473 methods in Simada area, northwestern Ethiopia. Geoenvironmental Disasters 7. https://doi.org/10.1186/s40677$\underline{020-00155-\mathrm{x}}$

475 Mishra V, Shah HL (2018) Hydroclimatological perspective of the Kerala flood of 2018. Journal of the Geological 476 Society of India 92: 645-650. https://doi.org/10.1007/s12594-018-1079-3

477 Moglen GE, Eltahir EAB, Bras RL (1998) On the sensitivity of drainage density to climate change. Water 478 Resources Research 34(4): 855-862.

479 Moore ID, Gessler PE, Nielsen GA, Peterson GA (1993) Soil attribute prediction using terrain analysis. Soil 480 Science Society of America Journal 57(2): 443-452. https://doi.org/10.2136/sssaj1993.03615995005700020058x 
Moore ID, Grayson RB, Ladson AR (1991) Digital terrain modelling: A review of hydrological, https://doi.org/10.1002/hyp.3360050103

Msabi MM, Makonyo M (2021) Flood susceptibility mapping using GIS and multi-criteria decision analysis: A case of Dodoma region, central Tanzania. Remote Sensing Applications: Society and Environment 21. https://doi.org/10.1016/j.rsase.2020.100445 assessment and monitoring through remote sensing and GIS in western tracts of Tamil Nadu, India, International Journal of Remote Sensing 32(18): 5157-5176. https://doi.org/10.1080/01431161.2010.494642

Orimoloye IR, Ololade OO, Mazinyo SP, Kalumba AM, Ekundayo OY, Busayo ET, Akinsanola AA, Nel W (2019) Spatial assessment of drought severity in Cape Town area, South Africa. Heliyon 5(7). https://doi.org/10.1016/j.heliyon.2019.e02148

Panda PK, Sahoo S (2015) Modelling of floodplain using recent technology. European Journal of Advances in Engineering and Technology 2(7): 23-28.

Paquette J, Lowry J (2012) Flood hazard modelling and risk assessment in the Nadi River Basin, Fiji, using GIS and MCDA. The South Pacific Journal of Natural and Applied Sciences 30(1): 33-43. https://doi.org/10.1071/SP12003

Parajuli A, Gautam AP, Sharma SP, Bhujel KB, Sharma G, Thapa PB, Bist BS, Poudel S (2020) Forest fire risk mapping using GIS and remote sensing in two major landscapes of Nepal. Geomatics, Natural Hazards and Risk 11(1): 2569-2586. https://doi.org/10.1080/19475705.2020.1853251

501

Petersen MS (2001) Impacts of flash floods. In: Gruntfest E, Handmer J (eds) Coping with flash floods. NATO science series (Series 2. Environmental security), vol 77. Springer, Dordrecht. https://doi.org/10.1007/978-94$\underline{010-0918-8 \_2}$

Prachansri S (2017) Analysis of soil and land cover parameters for flood hazard assessment; A case study of the Nam Chun watershed, Phetchabun, Thailand. International Institute for Geo-Information Science and Earth

from

507 https://webapps.itc.utwente.nl/librarywww/papers_2007/msc/aes/prachansri.pdf

508 Pratomo RA, Jetten V, Alkema D (2016) Rural flash-flood behaviour in Gouyave watershed, Grenada, Caribbean Island. Geoplanning Journal of Geomatics Planning 3(2): 161-170. https://doi.org/10.14710/geoplanning.3.2.161$\underline{170}$

511 Putra MSD, Andryana S, Fauziah, Gunaryati A (2018) Applications of fuzzy multicriteria decision making to complex engineering problems. Advances in Fuzzy Systems. https://doi.org/10.1155/2018/9094380

513 Rahman M, Ningsheng C, Islam MM, Dewan A, Iqbal J, Washakh RMA, Shufeng T (2019) Flood susceptibility 514 assessment in Bangladesh using machine learning and multi-criteria decision analysis. Earth Systems and 515 Environment 3: 585-601. https://doi.org/10.1007/s41748-019-00123-y

516 Saaty TL (1980) The analytic hierarchy process: planning, priority setting, resource allocation (Decision making 517 series). McGraw Hill, New York, United States of America.

518 Samanta S, Pal DK, Palsamanta B (2018) Flood susceptibility analysis through remote sensing, GIS and frequency 

river basin, Indo-Bangladesh Barind region. Applied Water Science 10. https://doi.org/10.1007/s13201-019$\underline{1102-\mathrm{x}}$

523 Setiawan I, Mahmud AR, Mansor S, Shariff ARM, Nuruddin AA (2004) GIS-grid-based and multi-criteria analysis for identifying and mapping peat swamp forest fire hazard in Pahang, Malaysia. Disaster Prevention and Management 13(5): 379-386. https://doi.org/10.1108/09653560410568507 Shahabi H, Hashim M (2015) Landslide susceptibility mapping using GIS-based statistical models and Remote sensing data in tropical environment. Scientific Reports 5. https://doi.org/10.1038/srep09899

528 Shahfahad, Mourya M, Kumari B, Tayyab M, Paarcha A, Asif, Rahman A (2020) Indices based assessment of 529 built-up density and urban expansion of fast-growing Surat city using multi-temporal Landsat data sets. 530 GeoJournal. https://doi.org/10.1007/s10708-020-10148-w

531 Shen L, Li C (2010) Water body extraction from Landsat ETM+ imagery using adaboost algorithm. 2010 18th 532 International Conference on Geoinformatics: 1-4. https://doi.org/10.1109/GEOINFORMATICS.2010.5567762

533 Smiley SL, Hambati H (2019) Impacts of flooding on drinking water access in Dar es Salaam, Tanzania: 534 implications for the sustainable development goals. Journal of Water, Sanitation and Hygiene for Development 9(2): 392-396. https://doi.org/10.2166/washdev.2019.168

536 Souissi D, Zouhri L, Hammami S, Msaddek MH, Zghibi A, Dlala M (2020) GIS-based MCDM - AHP modeling 537 for flood susceptibility mapping of arid areas, southeastern Tunisia. Geocarto International 35(9): 991-1017. 538 https://doi.org/10.1080/10106049.2019.1566405

539 Swain KC, Singha C, Nayak L (2020) Flood susceptibility mapping through the GIS-AHP technique using the 540 cloud. ISPRS International Journal of Geo-Information 9(12). https://doi.org/10.3390/ijgi9120720

541 Tehrany MS, Shabani F, Jebur MN, Hong H, Chen W, Xie X (2017) GIS-based spatial prediction of flood prone 542 areas using standalone frequency ratio, logistic regression, weight of evidence and their ensemble techniques. 543 Geomatics, Natural Hazards and Risk 8(2): 1538-1561. https://doi.org/10.1080/19475705.2017.1362038

544 Tehrany MS, Pradhan B, Mansor S, Ahmad N (2015) Flood susceptibility assessment using GIS-based support 545 vector machine model with different kernel types. CATENA 125: 91-101. 546 https://doi.org/10.1016/j.catena.2014.10.017

547 Tehrany MS, Kumar L, Jebur MN, Shabani F (2019) Evaluating the application of the statistical index method in 548 flood susceptibility mapping and its comparison with frequency ratio and logistic regression methods. Geomatics, 549 Natural Hazards and Risk 10(1): 79-101. https://doi.org/10.1080/19475705.2018.1506509

550 Tiryaki M, Karaca O (2018) Flood susceptibility mapping using GIS and multicriteria decision analysis: Saricay551 Çanakkale (Turkey). Arabian Journal of Geosciences 11. https://doi.org/10.1007/s12517-018-3675-3

552 Ullah K, Zhang J (2020) GIS-based flood hazard mapping using relative frequency ratio method: A case study of 553 Panjkora River Basin, eastern Hindu Kush, Pakistan. PLoS ONE 15(3). 554 https://doi.org/10.1371/journal.pone.0229153

555 Vojtek M, Vojteková J (2019) Flood Susceptibility Mapping on a National Scale in Slovakia Using the Analytical 556 Hierarchy Process. Water 11(2). https://doi.org/10.3390/w11020364

557 Yong B, Ren LL, Hong Y, Gourley JJ, Chen X, Zhang YJ, Yang XL, Zhang ZX, Wang WG (2012) A novel 558 multiple flow direction algorithm for computing the topographic wetness index. Hydrology Research 43(1-2): 
560 Zha Y, Gao J, Ni S (2003) Use of normalized difference built-up index in automatically mapping urban areas from

561 TM imagery. International Journal of Remote Sensing 24(3): 583-594. https://doi.org/10.1080/01431160304987

562 Zou KH, O’Malley AJ, Mauri L (2007) Receiver-Operating Characteristic analysis for evaluating diagnostic tests

563 and predictive models. Circulation 115(5): 654-657. https://doi.org/10.1161/CIRCULATIONAHA.105.594929 
Figures

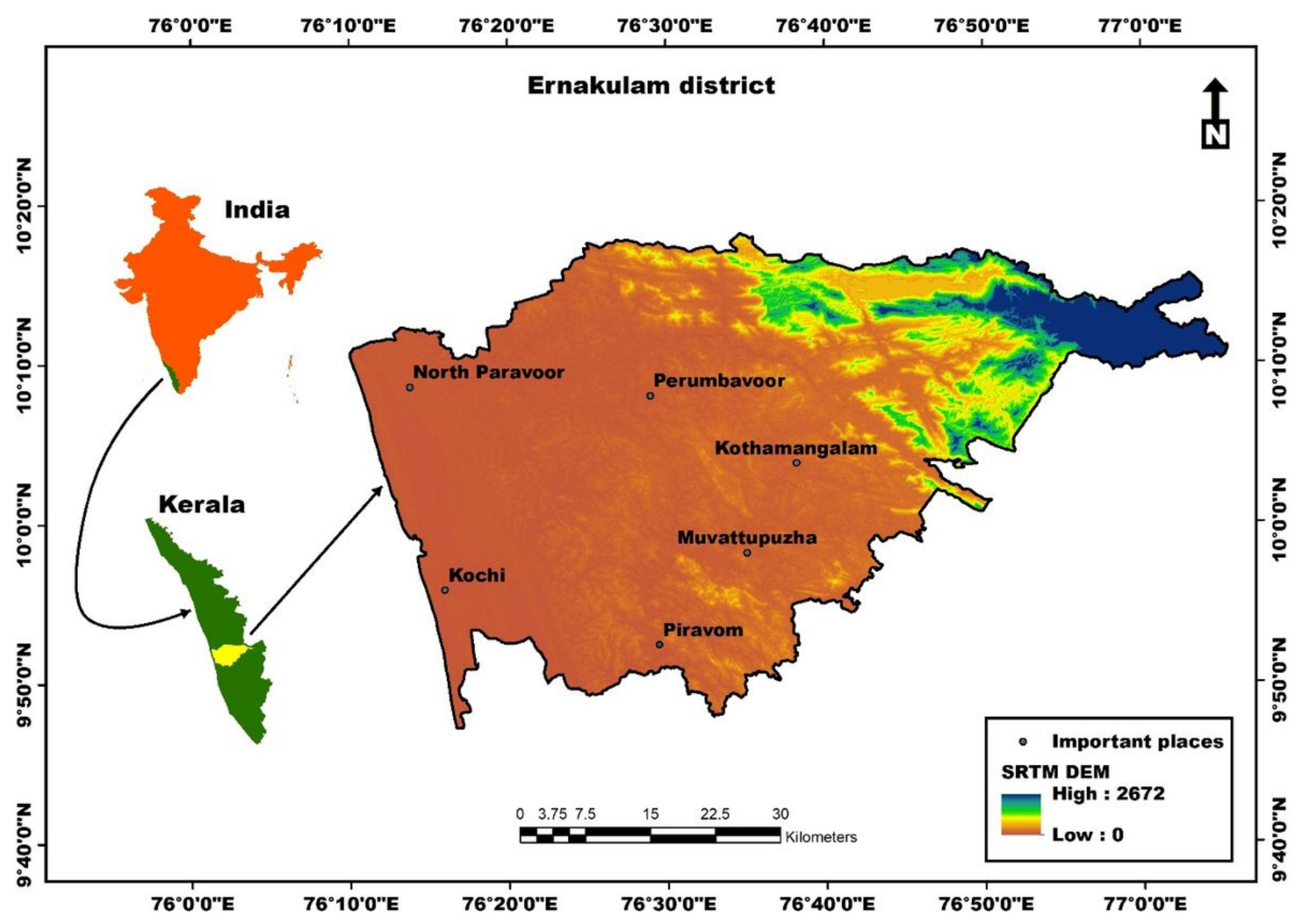

Figure 1

Location of the study area 


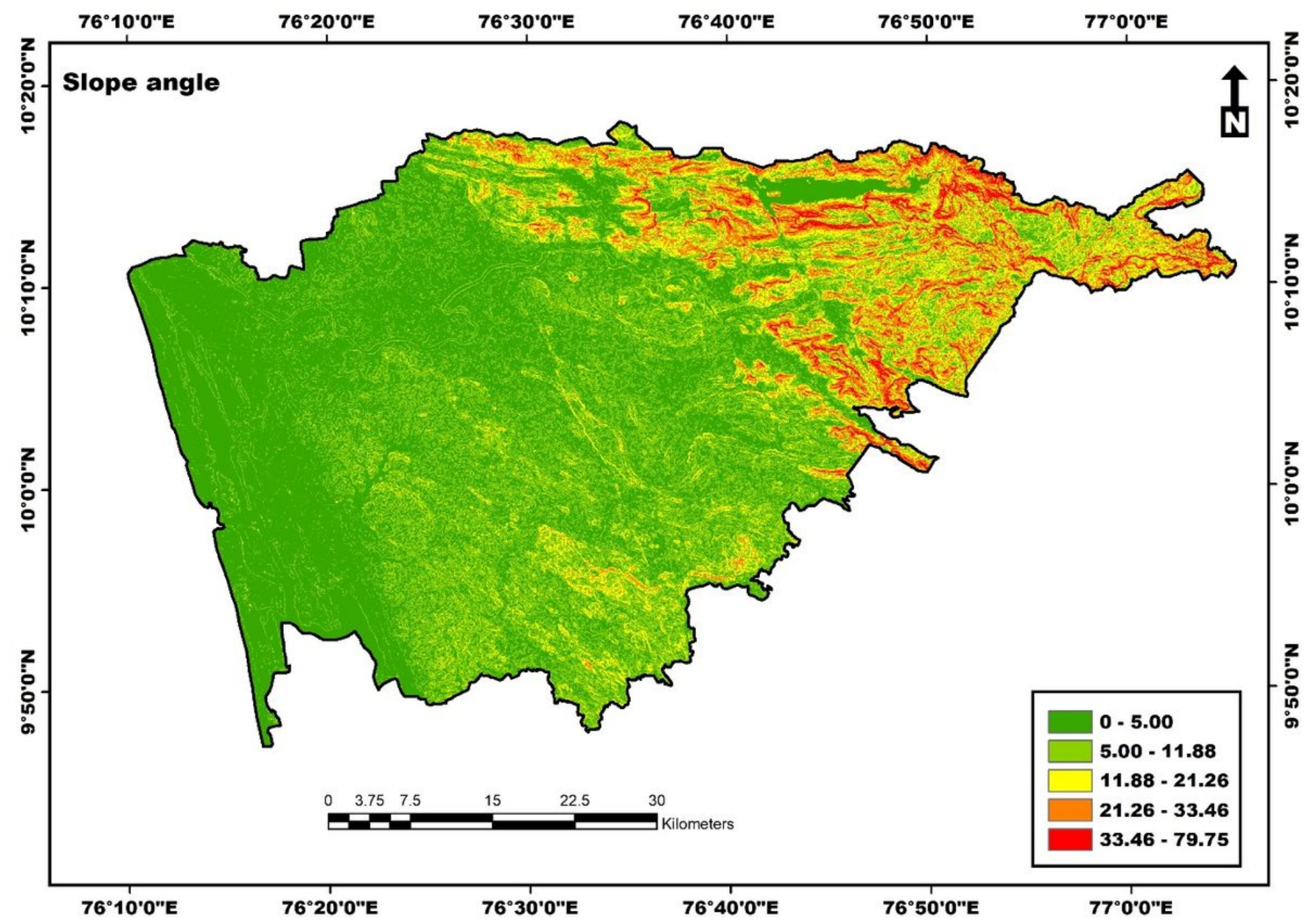

Figure 2

Slope 


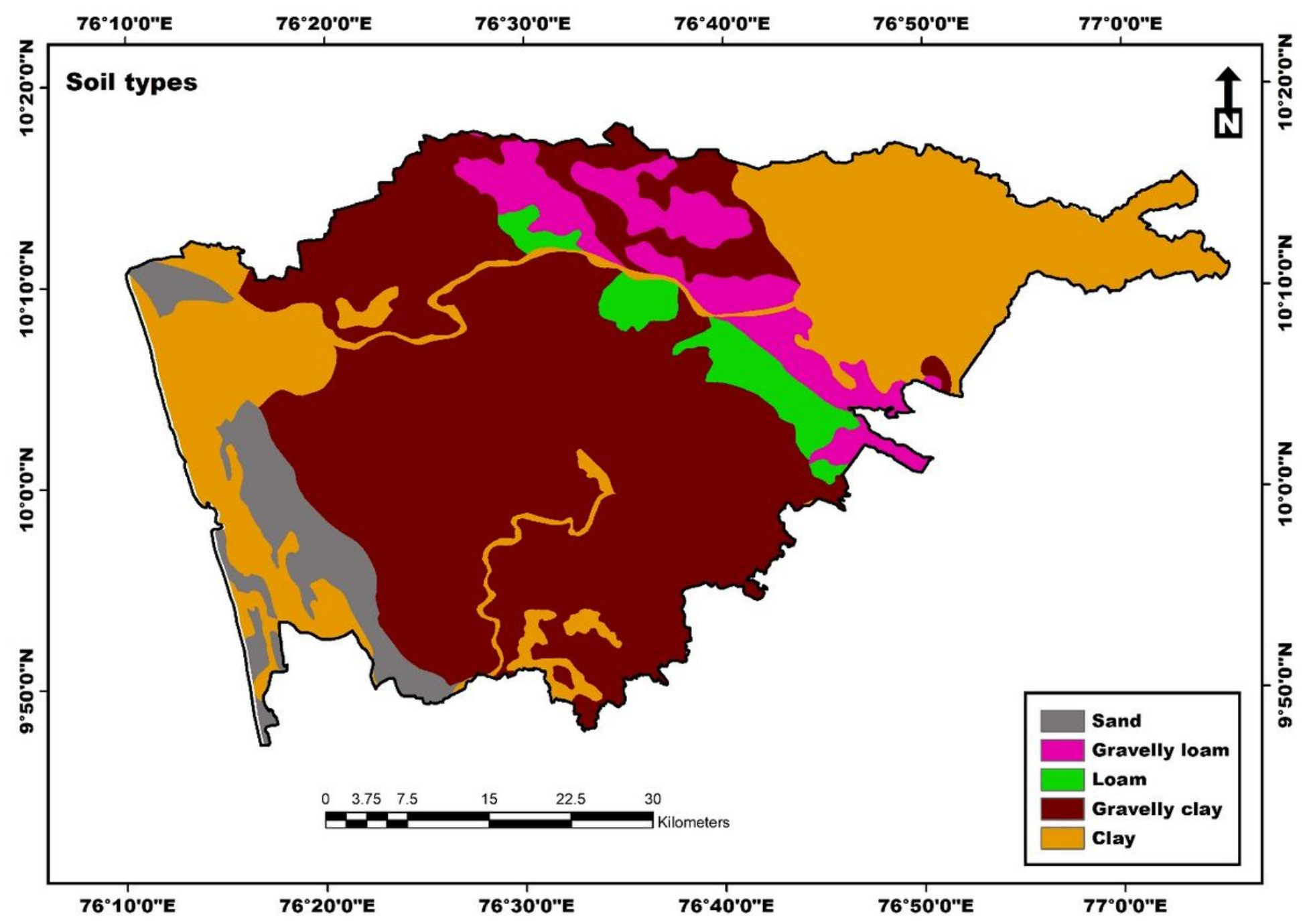

Figure 3

Soil types 


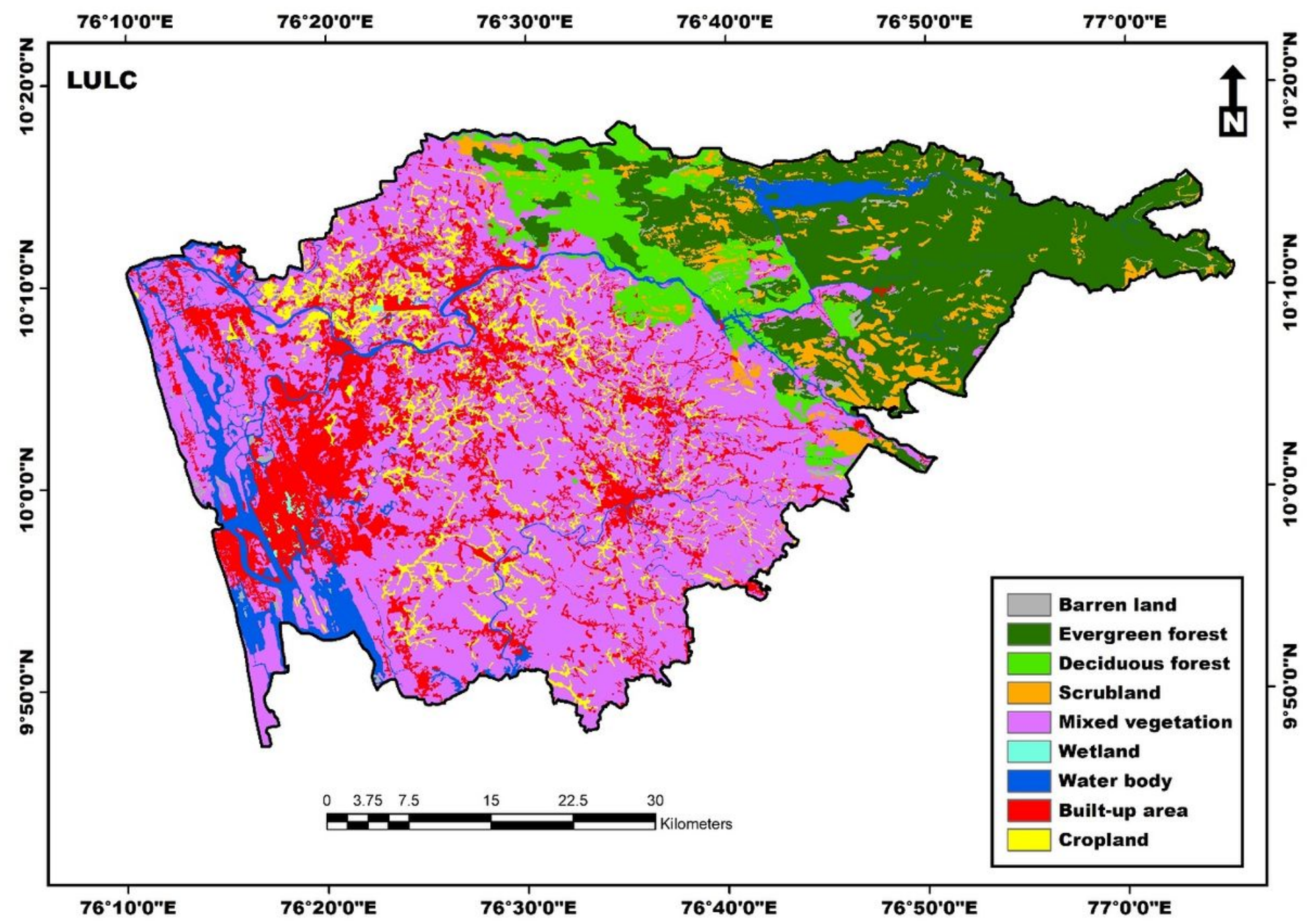

Figure 4

LULC 


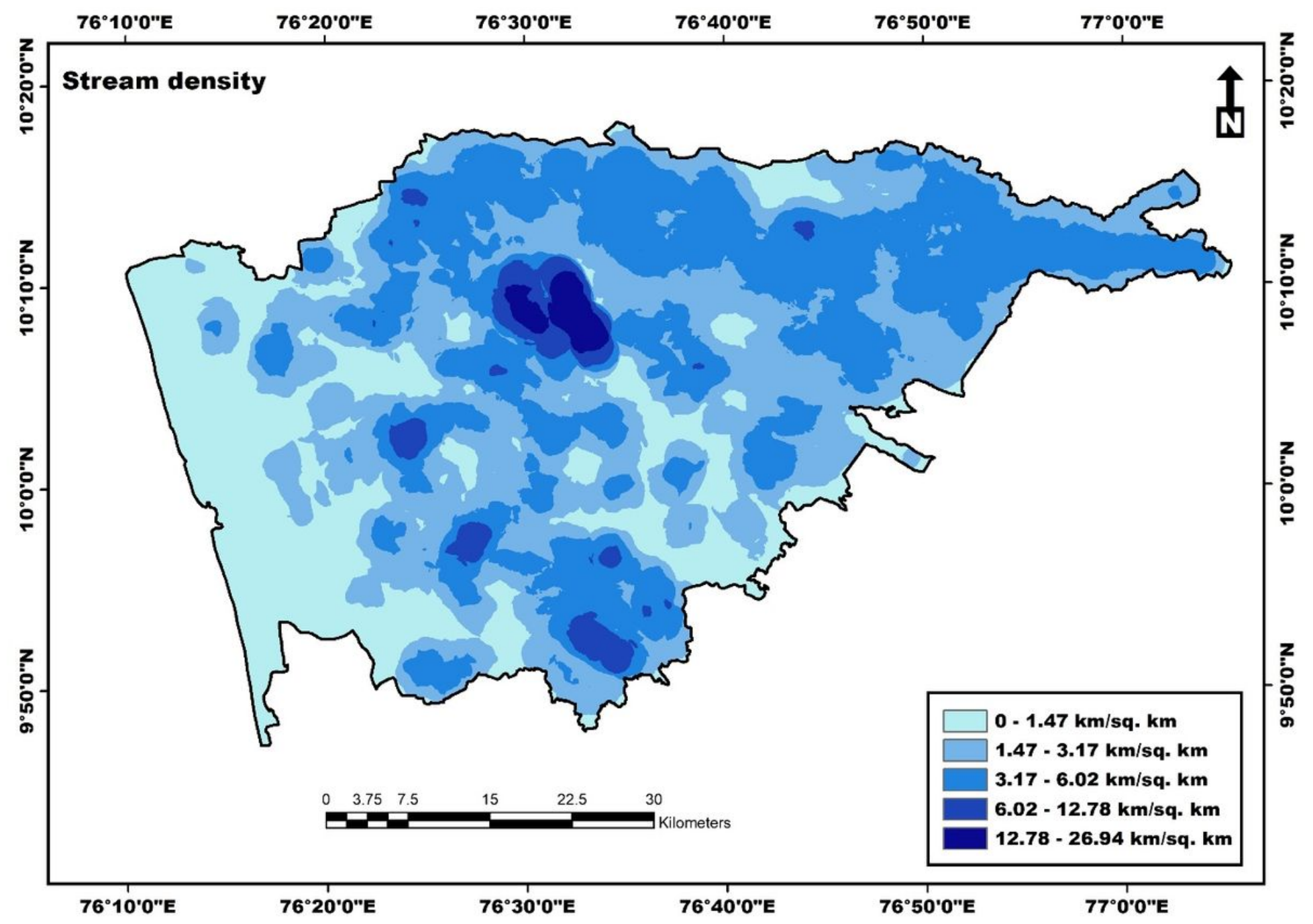

Figure 5

Stream Density 


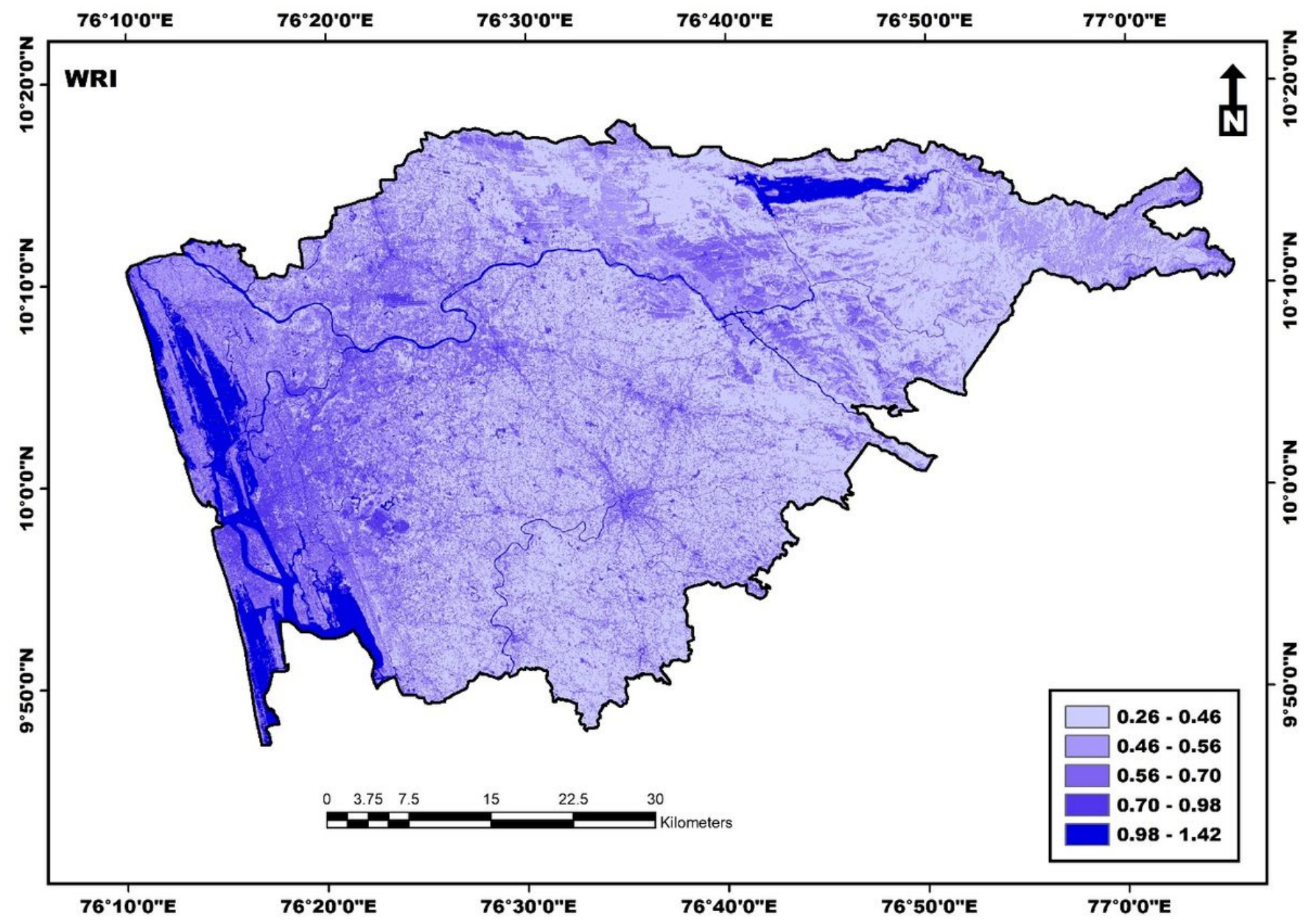

Figure 6

Water ratio index 


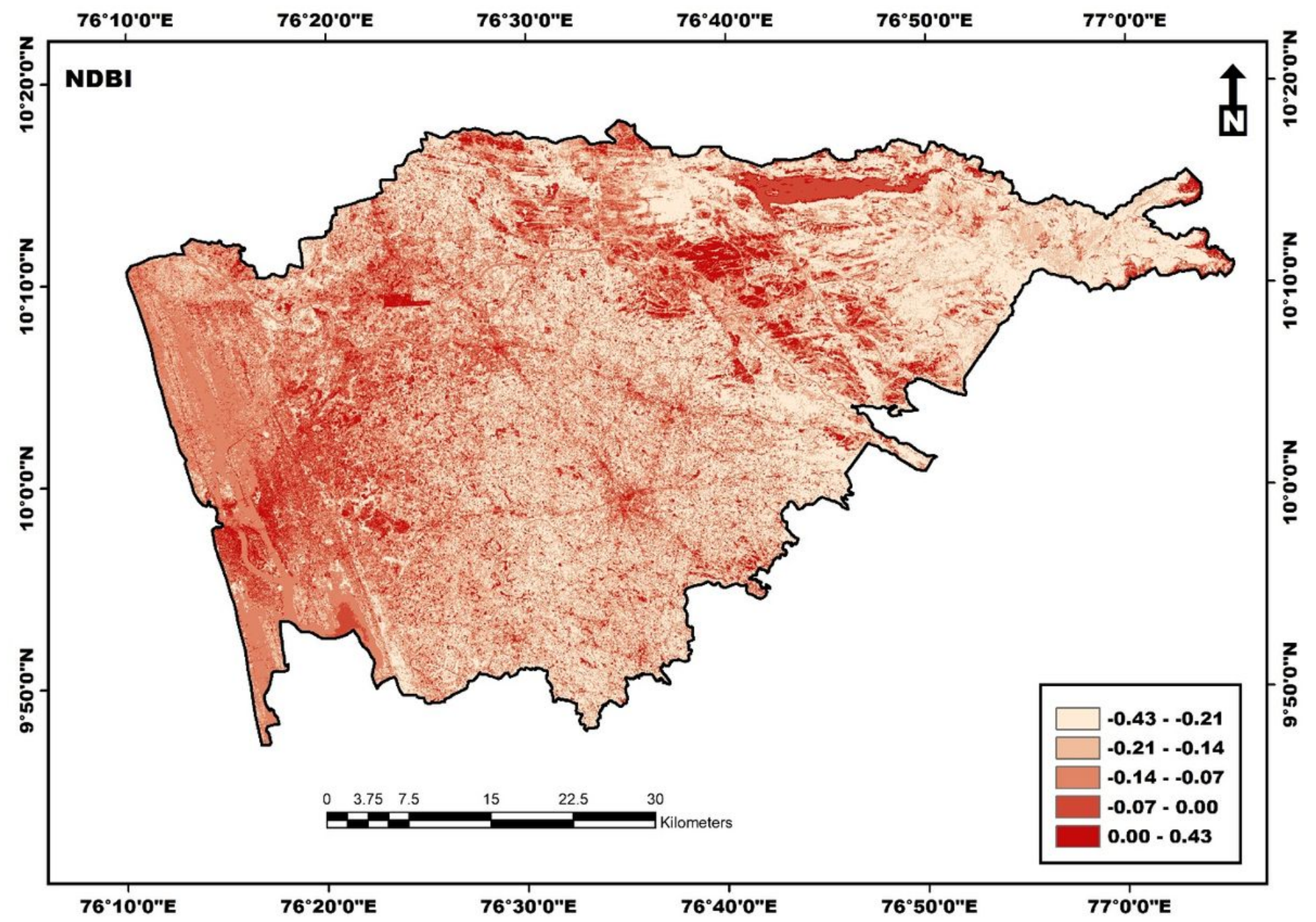

Figure 7

Normalized difference built-up index 


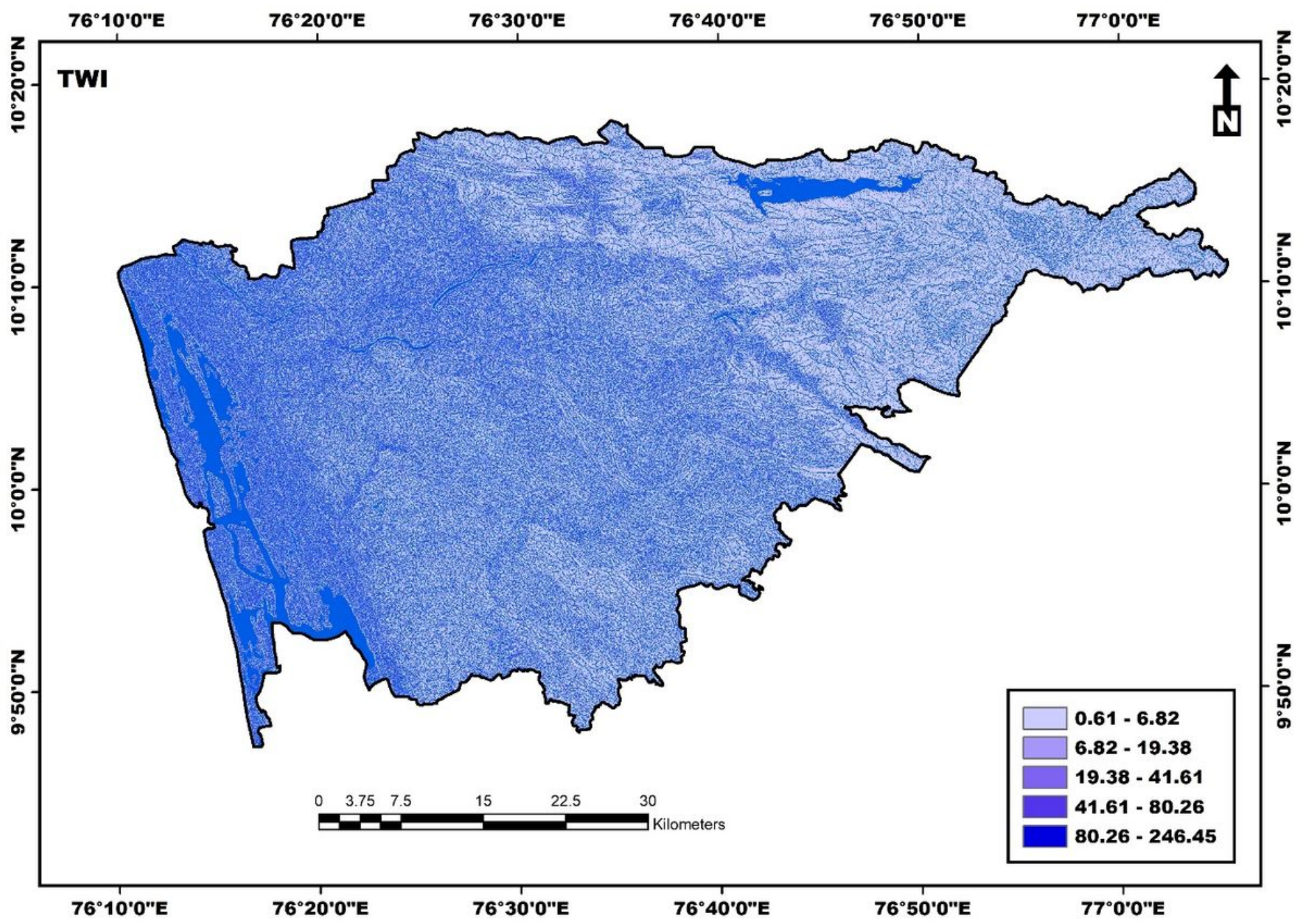

Figure 8

Topographic wetness index 


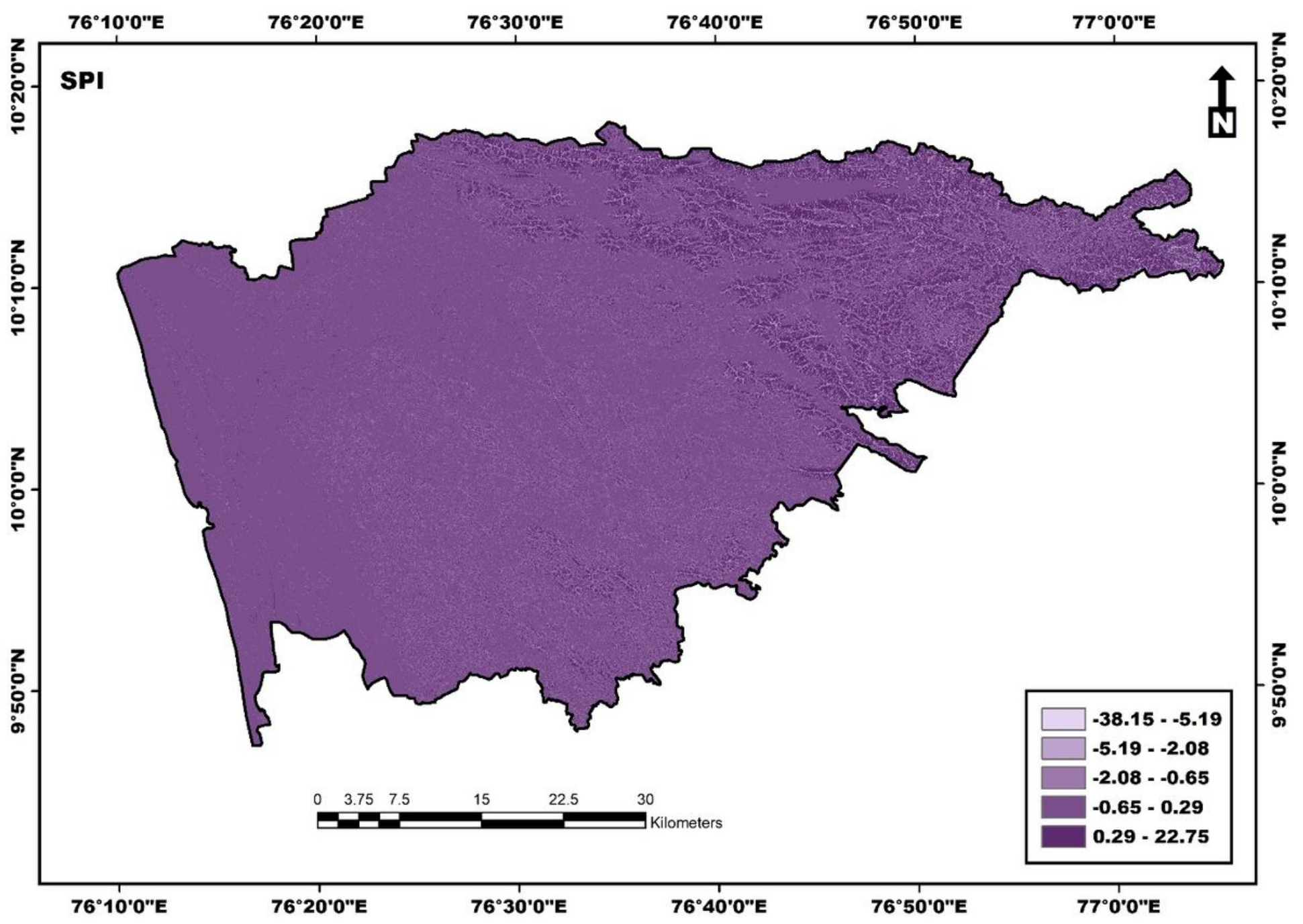

Figure 9

Stream power index 


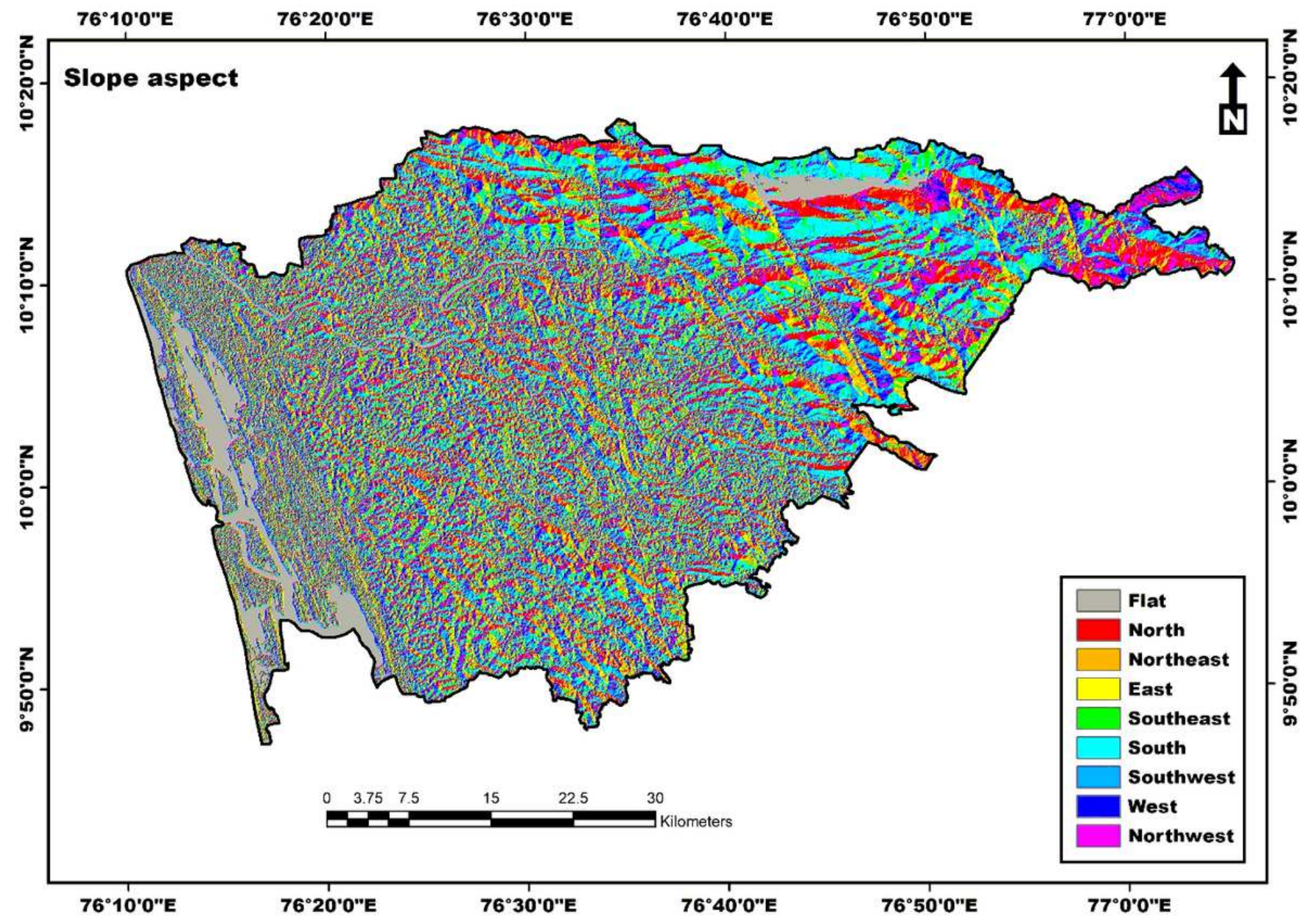

Figure 10

Slope Aspect 


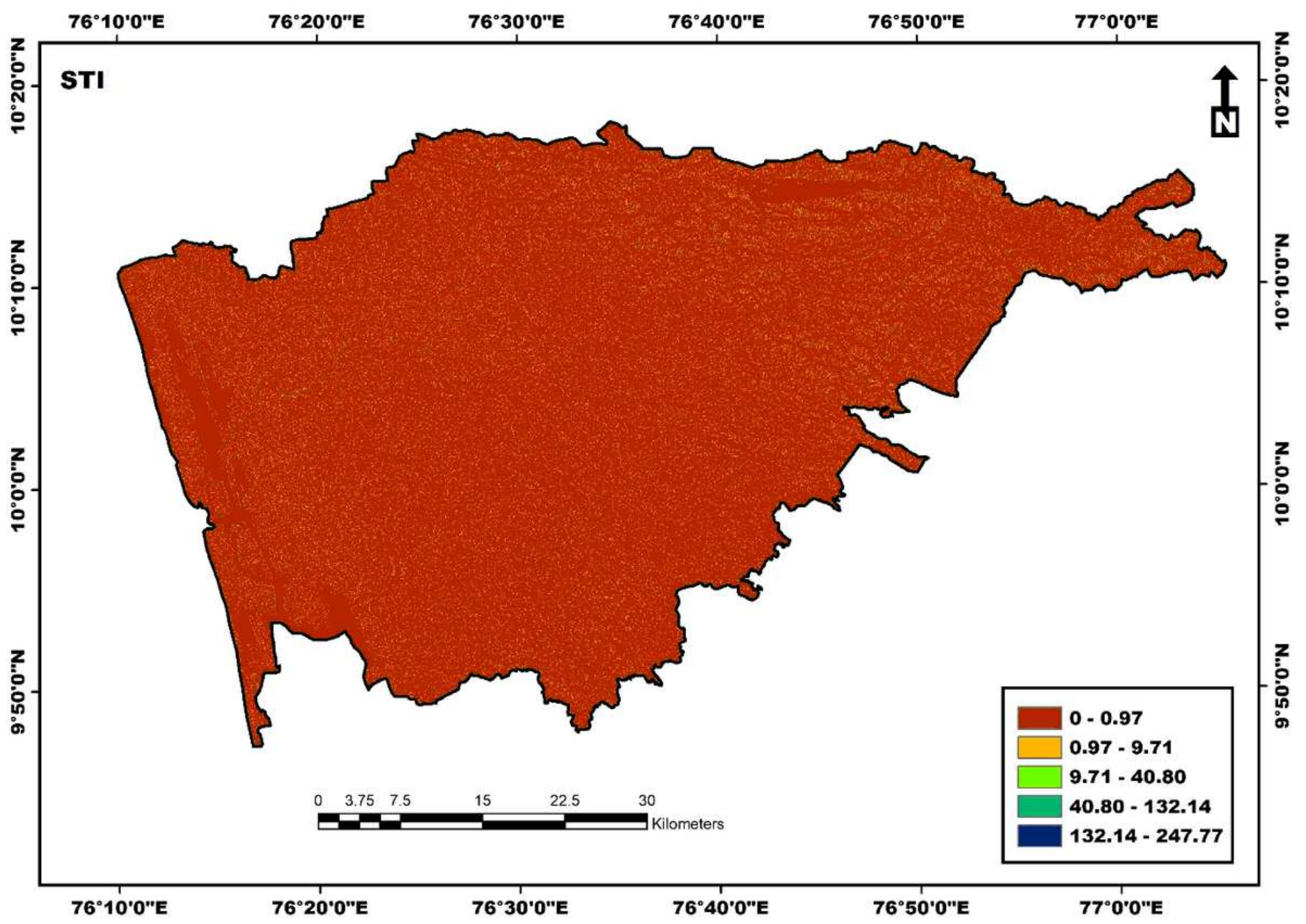

Figure 11

Sediment transport index 


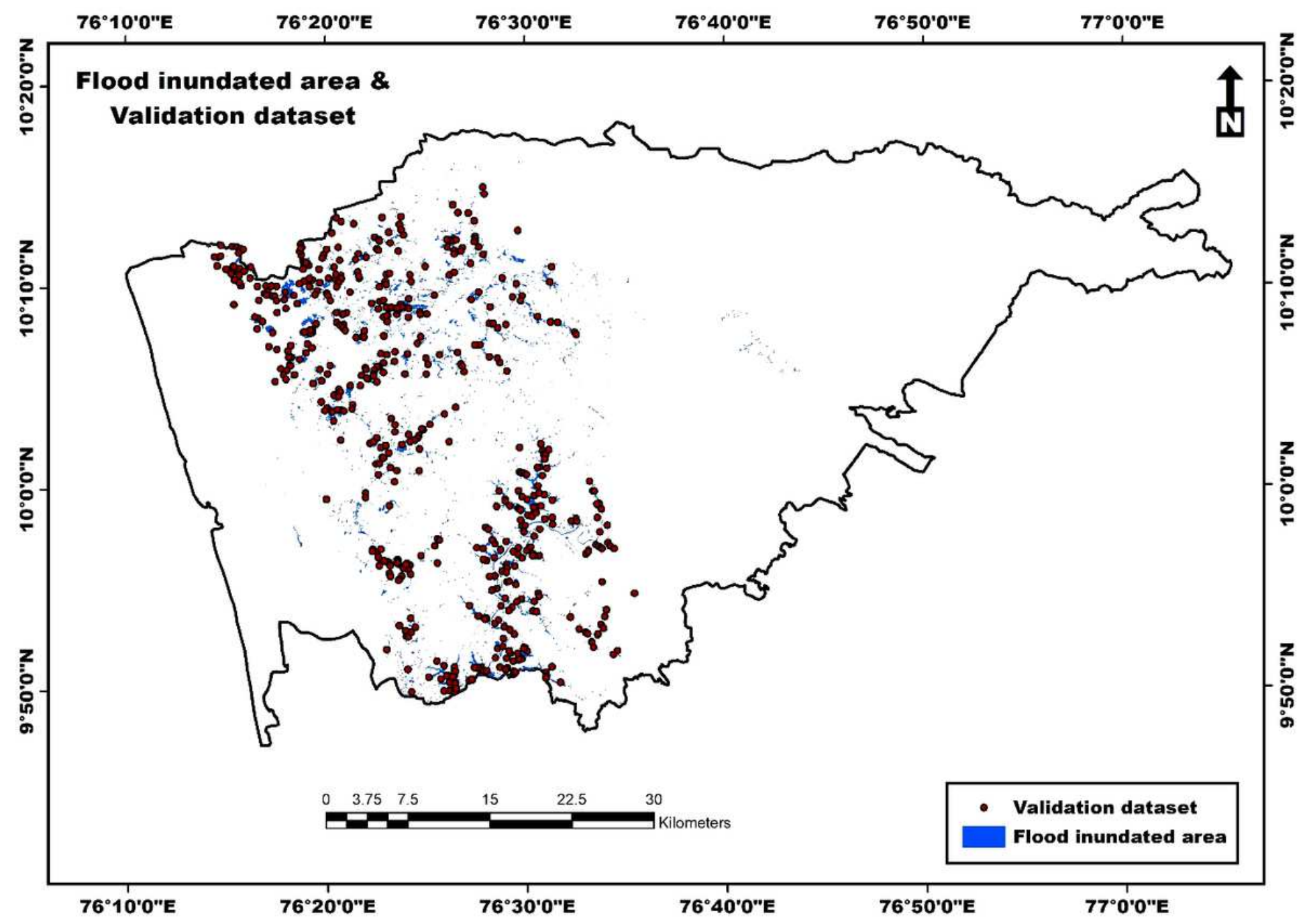

Figure 12

Flood inundation area 


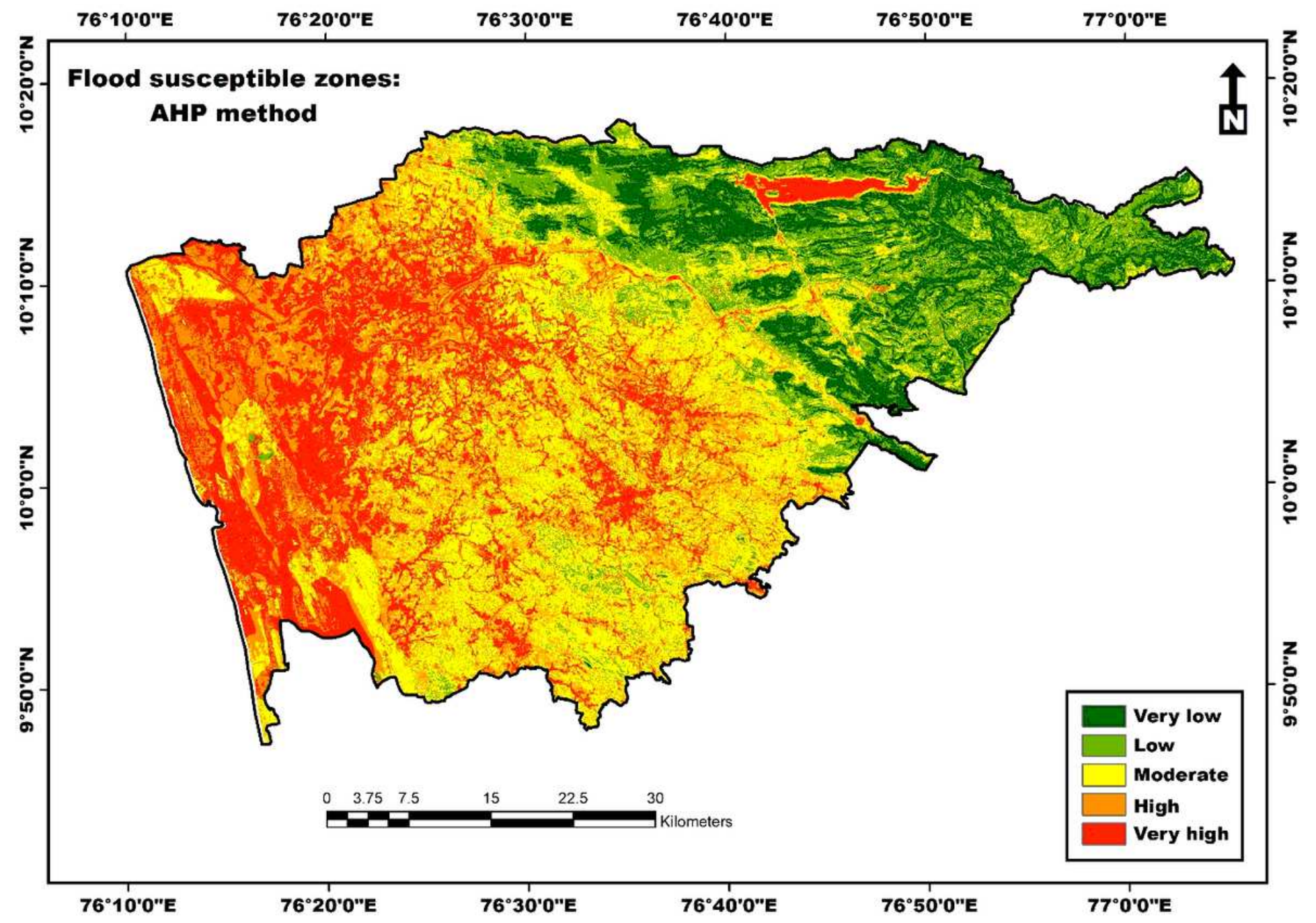

Figure 13

Flood susceptible zones: AHP method 


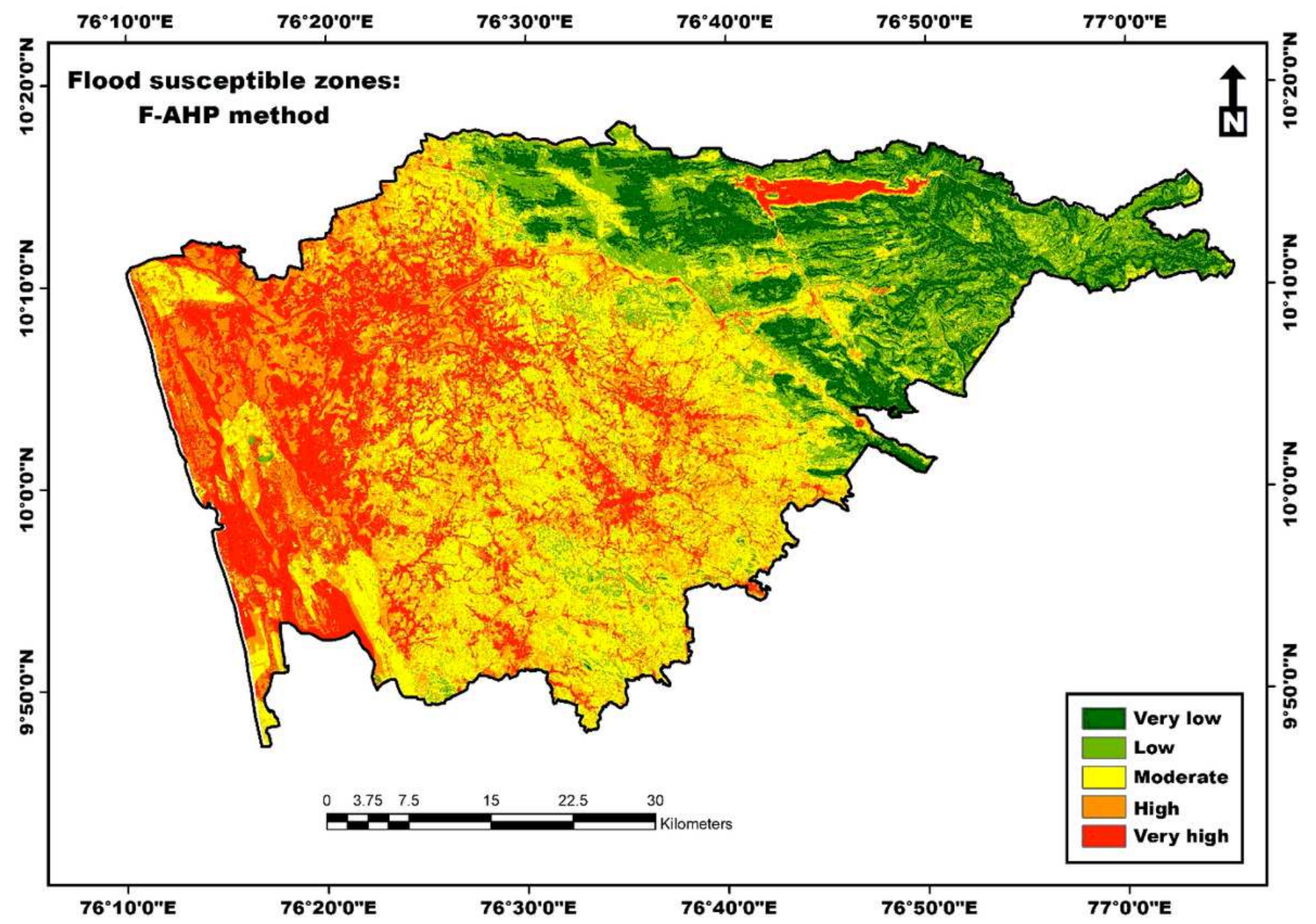

Figure 14

Flood susceptible zones: F-AHP method 


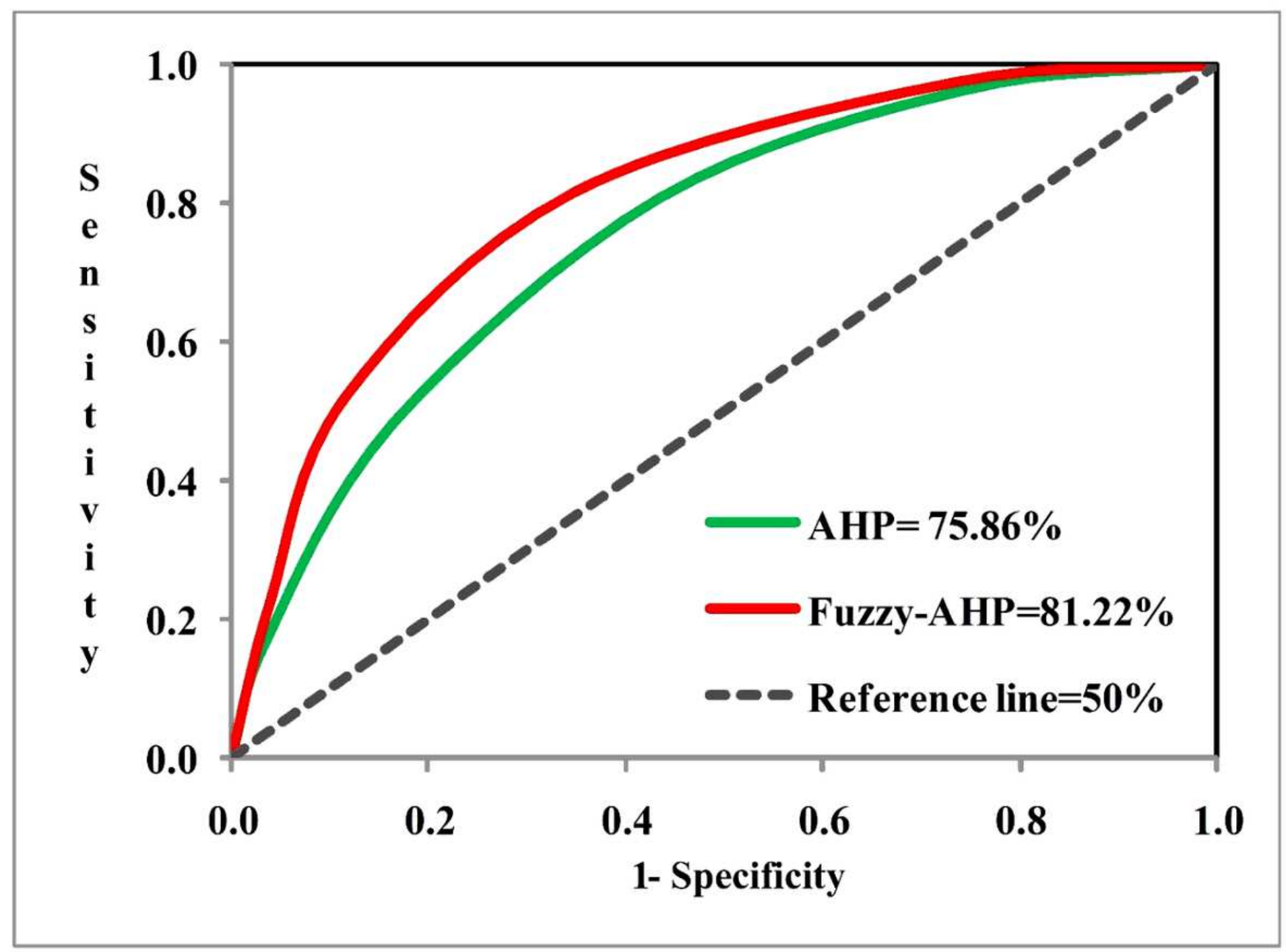

Figure 15

The ROC curves

\section{Supplementary Files}

This is a list of supplementary files associated with this preprint. Click to download.

- ManuscriptTables.docx 